\title{
ПОЛИСТАДИЙНАЯ ЭВОЛЮЦИЯ ПРОТЕРОЗОЙСКОЙ КОРЫ ВОСТОЧНОЙ АНТАРКТИДЫ НА ПРИМЕРЕ ТЕРРЕЙНА ФИЛЛА (ОСТРОВА РЁУЕР): НОВЫЕ ГЕОЛОГИЧЕСКИЕ И ИЗОТОПНЫЕ ДАННЫЕ
}

\author{
Алексеев Н. Л., Каменев И. А., Михальский Е. В., Ларионов А. Н., Капитонов И. Н., Богомолов Е. \\ С., Егоров М. С.
}

\begin{abstract}
Аннотация
В работе представлены новые данные по одному из уникальных объектов Восточноантарктического щита - островам группы Рёуер. Интерес к этому району диктуется его комплексным геологическим строением, включающим как архейские, так и протерозойские фрагменты земной коры, и полифазной структурой. В работе впервые предложена детальная схема геологического строения района с выделением новых вещественных комплексов и впервые получены надёжные датировки этапов тектономагматической деятельности на рубежах около 1400-1320 млн. лет и 1150 млн. лет назад, что создаёт фактологическую основу для сопоставления данной территории с другими районами Восточной Антарктиды. Полученные нами геологические и изотопные данные позволяют выделить в районе островов Рёуер мезо-неопротерозойский террейн Филла, сложенный метаморфическими и первично интрузивными породами, протолиты которых образовались в интервале времени 1400-950 млн. лет назад. В террейне Филла установлены три периода тектонотермальной активизации: среднемезопротерозойский в интервале времени 1400-1320 млн. лет, мезо-неопртерозойский в интервале 1150-886 млн. лет и раннекембрийский с возрастом 536-504 млн. лет. Первый период рассматривается как минимальное время формирования мезопротерозойской коры и, по времени, коррелируется с фазой тектогенеза в сопредельной провинции Рейнер. Интервал времени 1160-886 млн. лет соответствует более поздней фазе тектонотермальной активности провинции Рейнер. В террейне Филла этот период может быть разделен на два эпизода с возрастом 1150-1100 млн. лет и 1010-886 млн. лет. Первый эпизод интерпретируется как интенсивный рост коры за счет гранитоидного и мантийного магматизма. Интервал времени 1010-886 млн. лет рассматривается как эпизод тектонотермальной переработки, сопровождавшийся интенсивными деформациями, высокотемпературным метаморфизмом и внедрением интрузий порфировидных гранитоидов. Повидимому, в интервале времени между первым и вторым эпизодом, произошло отложение осадочного протолита парагнейсов, которые совместно с окружающими породами, подверглись высокотемпературному метаморфизму и деформациям на рубеже 950-914 млн. лет назад. Совместная эволюция архейского блока и Филла началась, как минимум, в интервале времени 1100-1000 млн. лет назад.
\end{abstract}

Наиболее молодой, раннекембрийский, период тектонической активизации сопровождался развитием локальных, относительно низкотемпературных зон милонитов и внедрением синкинематических жил пегматитов. Таким образом, тектонотермальная эволюция террейна Филла практически полностью соответствует основным фазам роста и переработки коры провинции Рейнер. Следовательно, террейн Филла представляет собой фрагмент провинции Рейнер, присоединенный к архейскому блоку, как минимум, в конце мезопротерозоя.

\section{Ключевые слова:}

$\mathrm{U}-\mathrm{Th}-\mathrm{Pb}$ датирование циркона (SHRIMP), Sm-Nd исследования «порода-гранат», мезопротерозой 


\title{
ПОЛИСТАДИЙНАЯ ЭВОЛЮЦИЯ ПРОТЕРОЗОЙСКОЙ КОРЫ ВОСТОЧНОЙ АНТАРКТИДЫ НА ПРИМЕРЕ ТЕРРЕЙНА ФИЛЛА (ОСТРОВА РЁУЕР): НОВЫЕ ГЕОЛОГИЧЕСКИЕ И ИЗОТОПНЫЕ ДАННЫЕ
}

\author{
Н.Л.Алексеев ${ }^{1,2}$, И.А.Каменев ${ }^{3}$, Е.В.Михальский ${ }^{4}$, А.Н. Ларионов ${ }^{1}$, И.Н. Капитонов ${ }^{1}$, \\ Е.С Богомолов ${ }^{1,2}$, М.С. Егоров ${ }^{3}$ \\ ${ }^{1}$ ФГБУ «Всероссийский научно-исследовательский геологический институт имени \\ А.П.Карпинского» (ВСЕГЕИ), 199106, С.-Петербург, Средний пр., д. 74; \\ nikola.alekseev@gmail.com \\ ${ }^{2}$ ФГБУН «Институт геологии и геохронологии докембрия РАН» (ИГГД), 199034, С.- \\ Петербург, наб. Макарова, д. 2 \\ ${ }^{3}$ АО «Полярная морская геологоразведочная экспедиция» (ПМГРЭ), 198412, С.-Петербург \\ - Ломоносов, ул. Победы, д. 24 \\ ${ }^{4}$ ФГБУ «ВНИИОкеангеология», 190121, С.-Петербург, Английский пр., д. 1
}

\section{ВВЕДЕНИЕ}

Район островов Рёуер на побережье залива Прюдс в Восточной Антарктиде является специфическим компонентом кристаллического фундамента ВосточноАнтарктической платформы [Равич, Каменев, 1972], поскольку сложен как архейскими, так и протерозойскими образованиями, претерпевшими неоднократные этапы тектонотермальной активизации. В данном секторе Восточной Антарктиды выделяются три крупных тектонических провинции (рис. 1а), определяемых спецификой истории геологического развития. В число этих провинций входят Рукерская провинция в южной части гор Принс-Чарльз (ГПЧ), провинция Вестфолль в восточной части побережья залива Прюдс и Рейнерская провинция, занимающая обширные пространства между ними [Tingey, 1991; Михальский, Шератон, 2011]. Рукерская провинция сложена, главным образом, геологическими комплексами, сформированными в интервалах времени 3500-2800 млн. лет и 2500-2100 млн. лет назад. Провинция Вестфолль преимущественно сложена ортогнейсами, протолиты которых кристаллизовались в интервале 2520-2450 млн. лет назад. Рейнерская провинция испытала комплексную полифазную геологическую историю в интервале от 1400 млн. лет до 900-850 млн. лет назад. В её пределах выделяются два основных тектономагматических эпизода с возрастом 1400-1200 млн. лет (Фишерская фаза) и 1150-930 млн. лет (Биверская фаза), а также эпизод интенсивного парциального плавления, метаморфизма и деформаций пород в интервале 950-850 млн. лет [Mikhalsky et al., 2013], которые могут рассматриваться в качестве фаз Рейнерского орогенического цикла. Некоторые участки территории Рейнерской провинции (в частности, острова Рёуер) были подвергнуты тектонотермальной переработке (высокотемпературный метаморфизм и деформации различного характера) в интервале 545-510 млн. лет назад, что позволяет некоторым авторам выделять дополнительно провинцию Рёуер [Harley et al., 1995].

Этот район привлекал и продолжает привлекать повышенное внимание исследователей. Первые сведения о геологическом строении района были получены отечественными геологами ещё в 1950-1960-ые годы (П.С. Воронов, Л.В. Климов, Д.С. 
Соловьёв, М.Г. Равич), которыми были заложены представления о геологическом развитии Восточной Антарктиды. В дальнейшем пристальное внимание к этому району уделялось австралийскими исследователями, разработавшими первую схему тектонического развития на базе U-Pb высокоточных локальных датировок циркона. Петрологические и геохронологические исследования позволили некоторым авторам выдвинуть гипотезу о коллизионном характере развития территории [Harley, 1988; Fitzsimons, 2000], что предопределило развитие представлений о композитном строении фундамента ВосточноАнтарктической платформы, сформировавшегося в результате коллизии нескольких континентальных блоков (рис. 1a; [Fitzsimons, 2003; Boger, 2011]).

В этой связи возник вопрос о более точном определении последовательности геологических событий в этом районе для выполнения обоснованного корреляционного и террейнового анализа. В период с 2011 г. по 2016 г. в районе островов Рёуер силами Полярной морской геологоразведочной экспедиции (ПМГРЭ) осуществлялось детальное геологическое картирование, материалы которого легли в основу данной работы. В работе приводится детальная характеристика вновь выделенных геологических подразделений и их взаимоотношений. Результаты U-Th-Pb датирования зерен циркона методом SHRIMP и LA-ICP-MS, а также Sm-Nd исследования пород и минералов (граната) использованы для выявления последовательности геологических событий на исследованной территории и их корреляции с соседней провинцией Рейнер.

\section{ГЕОЛОГИЧЕСКАЯ ХАРАКТЕРИСТИКА ОСТРОВОВ РЁУЕР}

Острова Рёуер, расположенные в восточной части побережья залива Прюдс (рис. 1a), состоят из метаморфизованных в гранулитовой фации ортогнейсов и подчиненного количества супракрустальных пород. Провинция Рёуер имеет сложное геологическое строение и включает в себя как протерозойские, так и архейские фрагменты коры [Kinny et al., 1993]. Последние были выделены в архейский террейн Мазе [Harley et al., 1995; Harley, Kelly, 2007a], в котором преобладают тоналитовые ортогнейсы с возрастом протолита более 3270 млн. лет и 2820-2800 млн. лет [Kinny et al., 1993]. Среди них, в виде вытянутых линзовидных тел протяженностью до нескольких км, установлены метаосадочные породы и гранатсодержащие гранулиты основного состава, известные под названием парагнейсов Мазе [Harley, Fitzsimons, 1991; Harley, 1987].

Протерозойские образования тектонически чередуются с архейскими ортогнейсами на юго-востоке провинции Рёуер (п-ов Мазе), что явилось результатом развития зон интенсивных сдвиговых деформаций, сопровождавшихся высокотемпературным метаморфизмом [Harley, 1987; Sims et al., 1997]. Породы протерозойского возраста резко преобладают или практически полностью слагают её северо-западную часть (острова Филла, Ефремова и др., рис. 1б), которую в данной работе впервые предлагается выделить в качестве мезо-неопротерозойского террейна Филла. Значения модельного Nd возраста для ортогнейсов и гранитоидов террейна Филла находятся в интервале 1.2-1.7 млрд. лет [Sheraton et al., 1984; Михальский и др., 2018], что говорит об их формировании за счет ювенильной протерозойской коры.

В провинции Рёуер ранее были установлены ортогнейсы с возрастом кристаллизации магматического протолита около 1050-950 млн. лет [Kinny et al., 1993], чередующиеся с мезопротерозойскими образованиями, представленными мигматизированными силлиманитсодержащими породами («парагнейсы Филла») и 
ассоциирующимися с ними гранулитами основного состава («метабазиты Филла»), предположительно вулканогенного происхождения [Harley and Fitzsimons, 1991; Harley et al., 1995].

Анатектическая выплавка лейкогранитного состава из метабазитов Филла имеет возраст 1057+22/-10 млн. лет [Kinny et al., 1993], что определяет минимальное время формирования протолита метабазитов. Датирование метаморфического монацита из парагнейсов Филла дает два пика U-Th-Pb возраста: более древний 1000-900 млн. лет и более молодой 540-510 млн. лет [Kinny, 1998; Kelsey et al., 2007, 2003a; Hokada et al., 2016].

Архейские и протерозойские образования интрудированы дайками базитов, которые интенсивно деформированы и метаморфизованы в условиях гранулитовой фации и могут быть подразделены на несколько генераций [Mikhalsky et al., 2019].

На основе изотопно-геохронологических и структурных исследований островов Рёуер было предложено несколько схем их тектонотермальной эволюции. Наиболее ранняя схема, предложенная [Harley, 1987], включала 5 эпизодов деформаций $\left(\boldsymbol{D}_{1}-\boldsymbol{D}_{5}\right)$, четыре из которых $\left(\boldsymbol{D}_{1}-\boldsymbol{D}_{4}\right)$ сопровождались высокотемпературным метаморфизмом. Эпизоды $\boldsymbol{D}_{\mathbf{1}}-\boldsymbol{D}_{2}$ рассматривались как архейские, $\boldsymbol{D}_{3}$ и $\boldsymbol{D}_{4}-$ как протерозойские и $\boldsymbol{D}_{5}-$ как кембрийский. Более поздние схемы тектонического развития [Harley et al., 1998; Sims et al., 1994; Dirks and Wilson, 1995] включали до восьми эпизодов деформаций (табл. 1). В данной работе мы придерживаемся, с некоторыми исключениями, схемы [Harley et al., 1987], как наиболее хорошо согласующейся с нашими полевыми наблюдениями, суммированными в таблице 1 , и представленными ниже изотопными данными. Однако, эпизоды $\boldsymbol{D}_{1}-\boldsymbol{D}_{2}$ нами рассматриваются как деформации протерозойского, а не архейского возраста. Деформации $\boldsymbol{D}_{\mathbf{1}}$ представлены метаморфической полосчатостью и сланцеватостью в комплексе Филла, а деформации $\boldsymbol{D}_{2}$ - сжатыми до изоклинальных складками в комплексе Филла. Деформации $\boldsymbol{D}_{3}$ привели к формированию повторной сжатой, до изоклинальной, складчатости $\boldsymbol{F}_{3}$, сопровождавшейся сланцеватостью их осевых плоскостей $\left(S_{3}\right)$. Эпизод $\boldsymbol{D}_{4}$ интерпретируется как основное деформационное событие в регионе, приведшее к формированию региональных линейных $30 н$ интенсивно деформированных пород («high-strain zone»), ориентированных в северо-северо-западном и субширотном направлении (рис. 1б). Этот эпизод сопровождался гранулитовым метаморфизмом пород [Sims, Wilson, 1997] и привел к развитию комплексной системы сопряженных зон сдвиговых деформаций (милонитов, или «shear-zones») в интенсивно деформированных доменах и комплексной складчатости в слабо деформированных доменах. Основные зоны милонитизации [Wilson et al., 2007], достигающие ширины более 1 км, ориентированы в субширотном направлении. Они сопряжены с зонами северозападной ориентировки, шириной до нескольких сот метров. В результате, более ранние плоскостные структуры, контакты между литологическими подразделениями и породами, включая дайки базитов, переориентированы либо в субширотном, либо в северо-западном направлении. Предшествующие $\boldsymbol{D}_{4}$ плоскостные структуры и складчатость, локально, сохраняются в слабо деформированных доменах.

$\mathrm{K}$ эпизоду деформаций $\boldsymbol{D}_{5}$ относится формирование локальных зон милонитов северо-западной или северо-северо-западной ориентировки, шириной до нескольких метров. По их осевой части происходило внедрение жил синкинематических пегматоидных гранитов с возрастом около 500 млн. лет [Kinny et al., 1993], пересекающих все предшествующие плоскостные структуры пород. 


\section{ГЕОЛОГИЧЕСКОЕ СТРОЕНИЕ ТЕРРЕЙНА ФИЛЛА}

Террейн Филла включает в себя метаморфизованные в гранулитовой фации парагнейсы и метабазиты Филла, объединённые в комплекс Филла, толщу мигматизированных гранат-биотитовых ( \pm ортопироксен) ортогнейсов и две устойчивые ассоциации метаморфизованных интрузивных пород: гранит-гранодиоритплагиогранитовую и габбронорит-диоритовую, а также порфировидные метагранодиориты, метадиориты и чарнокиты. Кроме того, встречаются жильные тела, представленные гранатсодержащими лейкогранитами, пегматитами, а также многочисленные дайки базитов.

Комплекс Филла по литологическим признакам подразделяется на три толщи (I, II, III). Породы всех толщ интенсивно мигматизированы, жильный материал имеет лейкогранитовый состав.

Толща I представлена чередованием тонко-мелкозернистых гомогенных или тонкополосчатых двупироксен-роговообманковых, двупироксен-биотитовых и гранатпироксен-роговообманковых кристаллических сланцев («метабазиты Филла»). Полосчатость выражена чередованием прослоев, обогащенных пироксенами, роговой обманкой или гранатом (рис. 2а). В подчиненном количестве присутствуют тонкие прослои и линзы лейкократовых биотит-ортопироксеновых и меланократовых клинопироксеновых или двупироксен- роговообманковых кристаллических сланцев, гранат-ортопироксеновых плагиогнейсов, ортопироксен-гранат-биотитовых и гранатортопироксеновых сланцев и силлиманит-гранатовых кварцитов. Видимая мощность толщи не превышает 300 м.

Толща II сложена чередующимися в разрезе гранат-биотитовыми сланцами, двупироксеновыми ( \pm роговая обманка), отопироксеновыми ( \pm биотит) и биотит-гранатортопироксеновыми лейкократовыми сланцами. Часто отмечается достаточно тонкое переслаивание этих разновидностей (рис. 2б). Гранат-биотитовые сланцы содержат вытянутые по сланцеватости линзы тонкозернистых клинопироксенсодержащих лейкократовых сланцев, возможно, представляющих собой деформированную гальку конгломератов. Все породы интенсивно мигматизированы; жильный материал представлен гранатсодержащим гранитом. Видимая мощность толщи не превышает 250 м.

Толща III представлена силлиманит-гранатовыми гнейсами и кварцитами («парагнейсы Филла») с редкими маломощными прослоями кристаллических сланцев, гранат-биотитовых и ортопироксен-гранатовых гнейсов. Редко отмечаются прослои ортопироксен- кордиеритовых пород. Кристаллические сланцы встречаются либо в виде линз в силлиманит-содержащих гнейсах, либо в виде отдельных прослоев, мощностью до 10 м. Они представлены, как правило, гранатсодержащими разновидностями с ортопироксеном и роговой обманкой. Видимая мощность толщи III около 230 м.

Полосчатые гранат-биотитовые (џортопироксен) ортогнейсы слагают согласные со сланцеватостью тела, видимой мощности до первых сотен метров. Ортогнейсы характеризуются постепенными переходами от гранат-биотитовых разновидностей без ортопироксена к ортопироксенсодержащим разновидностям (рис. 2в). В некоторых участках, в гранат-биотитовых гнейсах отмечаются реликты порфировидных вкрапленников калиевого полевого шпата (рис. 2г), которые указывают на первичномагматическую природу этих пород. Как правило, породы интенсивно инъецированы 
послойными жилами лейкократовых гранатсодержащих гранитов. Относительное возрастное положение пород определяется тем, что они интрудированы породами гранитгранодиорит-плагиогранитовой ассоциации, габбронорит-диоритовой ассоциации, телами чарнокитоидов и дайками метабазитов.

Гранит-гранодиорит-плагиогранитовая ассоциация представлена интенсивно деформированными, гранодиорито- гнейсами, тоналито- и плагиогранито-гнейсами локально инъецированными гранитными жилами. Они представлены, в основном, среднезернистыми, в разной степени рассланцованными биотит-ортопироксеновыми (土гранат) гранитоидами, слагающими извилистые, вытянутые по преобладающей сланцеватости тела с видимой мощностью от первых до 500 метров. Гранитоиды деформированы сжатыми складками $\boldsymbol{F}_{3}$, сопровождающимися сланцеватостью вдоль их осевых плоскостей (эпизод $\boldsymbol{D}_{3}$ ). Они интрудируют толщи I и II комплекса Филла, и часто содержат их многочисленные деформированные ксенолиты и крупные блоки (рис. За). В зонах интенсивного рассланцевания породы приобретают метаморфическую полосчатость и инъецированы жилами гранитного состава (рис. Зб). В свою очередь гранитоиды интрудируются порфировидными гранат-ортопироксеновыми гранитоидами с возрастом $1027 \pm 27$ млн. лет и 1000+51/-37 млн. лет [Kinny et al., 1993], породами габброноритдиоритовой ассоциации, а также жилами чарнокитоидов и дайками базитов.

Габбронорит-диоритовая ассоциация слагает обособленные тела видимой мощностью от нескольких десятков до сотен метров. Внедрение габбронорит-диоритов происходило до формирования комплексных зон милонитов $\boldsymbol{D}_{4}$, возможно, синхронно с развитием сланцеватости $\boldsymbol{S}_{3}$, сопровождающей эпизод деформаций $\boldsymbol{D}_{3}$ (табл. 1 ). Относительное возрастное положение этих пород определяется тем, что они интрудируют полосчатые кристаллические сланцы толщи I комплекса Филла (рис. Зв) и ортогнейсы гранит-гранодиорит-плагиогранитовой ассоциации. В свою очередь, габброиды интрудируются жилами чарнокитоидов, и аплитовидными ортопироксенсодержащими гранитами (рис. Зг), иногда с образованием интрузивной брекчии. Аналогичные аплитовидные граниты, пересекающие ортогнейсы, содержат циркон с возрастом $1004 \pm 52$ млн. лет [Kinny et al., 1993], что интерпретируется как время их кристаллизации.

Тела габброидов варьируют по составу от меланократовых габброноритов до лейкогабброноритов, двупироксеновых габбродиоритов и диоритов, что позволяет предположить многофазовый характер их внедрения. Основная масса пород представлена преимущественно однородными среднезернистыми габброноритами. В зонах милонитизации они превращены в кристаллические сланцы. В подчинённом количестве находятся порфировидные разновидности метагабброноритов, подразделяющихся на пироксен- и плагиоклаз-порфировидные (рис. Зг). Среди этих пород выделяются две разновидности: с вкрапленниками ортопироксена, окружёнными более мелкими зёрнами клинопироксена (рис. Зд), и с вкрапленниками клинопироксена, окружёнными более мелкими зёрнами ортопироксена и биотита (рис. Зе).

Порфировидные биотит-ортопироксеновые гранодиориты и диориты представлены представлены средне-крупнозернистыми разновидностями, часто с порфировидными вкрапленниками полевого шпата или их реликтами. Зачастую в породах отмечается гранат. По составу они меняются от диоритов до кварцевых монцодиоритов. В некоторых случаях по породам развивается грубая инъекционная мигматитовая полосчатость с жильным материалом, представленным лейкогранитом. 
Порфировидный гранитогнейс с острова Филла и кварцевый монцодиорит с острова Хоп содержат циркон с возрастом 1027 27 млн лет и 1000+51/-37 млн лет, соответственно, что интерпретируются как время их кристаллизации [Kinny et al, 1993].

Чарнокитоиды представлены слабо рассланцованными средне-крупнозернистыми разновидностями ортопироксенсодержащих гранитов и плагиогранитов, иногда с биотитом и гранатом. Они слагают жилы и более крупные тела с видимой мощностью до 500 м. Для них характерно присутствие многочисленных ксенолитов вмещающих пород. Их относительное возрастное положение определяется тем, что они интрудируют метаморфизованные порфировидные гранодиориты и диориты, некоторые разновидности даек базитов, а сами пересекаются жилами пегматитов.

Все перечисленные породы интрудируются жилами гранатовых лейкогранитов и пегматитов с возрастом около 500 млн лет [Kinny et al., 1993]. Все породы, за исключением жил пегматитов, подвергаются деформациям $\boldsymbol{D}_{4}$ и $\boldsymbol{D}_{5 \cdot=}$

\section{МЕТОДИКА U-Th-Рb ИССЛЕДОВАНИЙ}

Изотопный анализ циркона из первично интрузивных пород гранит-гранодиоритплагиогранитовой (образцы 59508, 59533-4, 59549 и 59549-7) и габбронорит-диоритовой ассоциаций (образец 59569-9b), из толщи I серии Филла (образец 59595-7) и толщи гранатбиотитовых ( \pm ортопироксен) ортогнейсов (образец 59583), был выполнен на ионном микрозонде SHRIMP-II в Центре изотопных исследований ВСЕГЕИ. Внутреннее строение зерен циркона было предварительно изучено в катодолюминесценции (КЛ). Диаметр пучка при локальных измерениях составлял 18-20 $\mu \mathrm{m}$, первичный ток - около 4 пА. Pb/U соотношения нормализировались к стандарту TEMORA-2 [Black et al., 2003]. Содержание обыкновенного свинца $\left(\mathrm{Pb}_{\mathrm{c}}\right)$ было скорректировано по измеренному содержанию ${ }^{204} \mathrm{~Pb}$. Вторичный стандарт 91500 [Wiedenbeck et al., 1995] использовался для контроля точности $\mathrm{Pb} / \mathrm{U}$ отношения и расчёта концентраций U, Th и Pb. Результаты измерений представлены в таблице 2 (Дополнительные материалы).

Циркон из образца метаосадочной породы толщи III комплекса Филла (образец 57563) анализировался методом LA-ICP-MS в Центре изотопных исследований ВСЕГЕИ с использованием волнового ArFeximer лазера COMPex-102, абляционной системы DUV193 и мультиколлекторного масс-спектрометра “Neptune”. Величина массфракционирования составляла около $1 \%$ на единицу массы, а стабильность этого параметра - около 0,0002. Pb/U отношения нормализовались к стандартам TEMORA и 91500; типичный диаметр пучка составлял около $50 \mu \mathrm{m}$. Результаты анализа приведены в таблице 3 (Дополнительные материалы). Если не оговорено особо, то все приводимые значения возраста соответствуют «конкордному» возрасту («Concordia age», [Ludwig, 2003]), а приводимые погрешности соответствуют $2 \sigma$.

\section{РЕЗУЛЬТАТЫ ИЗОТОПНЫХ ИССЛЕДОВАНИЙ}

Образец 59583 отобран из толщи гранат-биотитовых ( \pm ортопироксен) ортогнейсов). Циркон в этом образце представлен субпризматическими зёрнами со скругленными гранями дипирамиды. Реже встречаются субизометричные округлые зёрна. Часто зёрна трещиноваты, а трещины залечены новым, как правило, ярким в катодолюминесценции (КЛ) материалом циркона. В КЛ практически во всех зёрнах устанавливается светлое ядро 
с первично-магматической (осцилляторной) зональностью (рис. 4а). Ядра окружены тёмной незональной или слабо зональной оболочкой с постепенными переходами к ядру, что можно интерпретировать как результат перекристаллизации первично магматического циркона («ZCA-zoning», [Vavra et al., 1999]).

Было выполнено 12 анализов зёрен циркона. За исключением анализа 4.2 (тёмная оболочка), все остальные анализы характеризуются низким содержанием $U=249-519$ ppm и Th/U = 0,25-0,48 (табл. 2, Дополнительные материалы). Анализ тёмной каймы (4.2) отличается значительно более высоким содержанием $U=1029$ ppm и наиболее низким отношением $\mathrm{Th} / \mathrm{U}=0,21$. Четыре анализа оказались дискордантными, а остальные распределены по конкордии в интервале от $1408 \pm 26$ млн. лет до $1320 \pm 27$ млн. лет. Анализ темной оболочки (4.2) имеет статистически неотличимый от анализов ядер возраст $1367 \pm 20$ млн. лет.

Десять анализов ложатся на линию регрессии, образующую нижнее пресечение с

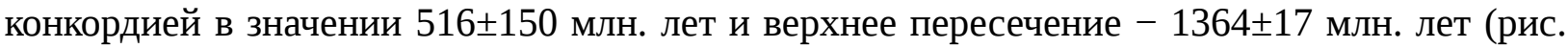
5а). Семь анализов ядер образуют когерентную группу с возрастом $1379 \pm 11$ млн. лет (рис. 5а, врезка), что в пределах погрешности совпадает с верхним пересечением линии регрессии. Значение $1364 \pm 17$ млн. лет интерпретируется как минимальное время кристаллизации магматического циркона в протолите ортогнейсов.

Образец двупироксен-рогвообманкового плагиосланца (59595-7), отобран из фрагмента толщи I комплекса Филла, характеризующегося ярко выраженной сланцеватостью $S_{3}$. Циркон, выделенный из этого образца, представлен мелкими (до 100 $\mu \mathrm{m})$ зернами или их фрагментами. Они имеют округлую, реже угловатую форму. Одно зерно (6.1) является длиннопризматическим со сглаженными и корродированными гранями. В катодолюминесценции большинство зерен обладает нечеткой пятнистой или секторной зональностью, вызванной чередованием более темных и более светлых полос и пятен (4.1, рис. 4б). Морфология и внутренне строение этих зерен предполагают их метаморфогенное происхождение (Vavra et al., 1996, 1999, Rubatto, 2017). Ядро зерна 8.1 отличается грубой планарной зональностью, часто встречающейся в магматическом цирконе из базитов. Оно окружено светлой незональной оболочкой (8.2). В зерне 9 наблюдается светлое ядро угловатой формы, окруженное тёмно-серой оболочкой (9.2). В зерне 6.1 (рис. 4б) сохраняются реликты концентрической, по-видимому, первично магматической, зональности. Поскольку это единичное зерно, то однозначно интерпретировать его происхождение затруднительно: оно может быть либо ксеногенным, либо первично магматическим, кристаллизовавшимся в протолите сланцев.

Было выполнено 14 анализов зёрен циркона. Все анализы оказались конкордантными или близконкордантными. За исключением анализа 6.1, они характеризуются содержанием $\mathrm{U}=165-613 \mathrm{ppm}, \mathrm{Th}=82-419 \mathrm{ppm}$ и $\mathrm{Th} / \mathrm{U}=0,25-0,75$. Анализ 6.1 отличается более высоким содержанием $\mathrm{U}$ и $\mathrm{Th}$, а его $\mathrm{Th} / \mathrm{U}=0,35$.

По анализу 6.1 рассчитан возраст $1342 \pm 19$ млн. лет (рис. 5б), что, в случае ксеногенной природы зерна, может интерпретироваться как максимальный возраст кристаллизации протолита сланцев. Зерно 9 характеризуется обратной зональностью: светлое ядро дает возраст 874 \pm 25 млн. лет, а тёмно-серая оболочка 1032 25 млн. лет. Анализы ядра 8.1 и оболочки 8.2 дают статистически неотличимые значения возраста $1014 \pm 24$ млн. лет и 994 \pm 27 млн. лет, соответственно. Вместе с другими пятью анализами, выполненными как по центральным, так и по краевым частям зерен, они образуют

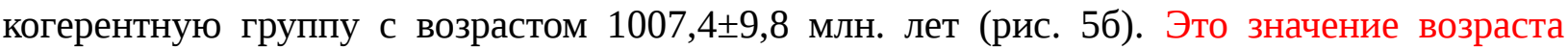


можно интерпретировать как время проявления наложенного термального события, возможно, синхронного с деформациями $\boldsymbol{D}_{3}$, сопровождавшегося кристаллизацией метаморфогенного или перекристаллизацией магматического циркона в протолите сланцев. Значения возраста остальных анализов находятся в пределах от $909 \pm 28$ млн. лет

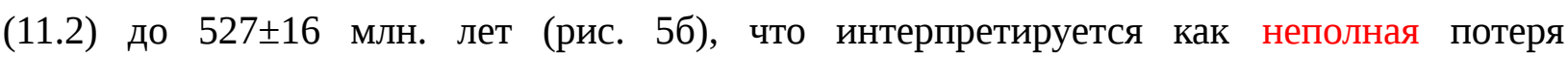
радиогенного $\mathrm{Pb}$ при более позднем наложенном термальном событии [Vavra et al., 1999].

Образец 59508 отобран из рассланцованных биотит-ортопироксеновых ортогнейсов гранодиоритового состава. Выделенный из этого образца циркон представлен зернами двух основных морфологических типов: I - резко удлинённые субпризматические до игольчатых зёрна со скругленными гранями дипирамиды и II - овальными или угловатыми зёрнами. Циркон I типа содержит (9.1), в основном, грубо полосчатое зональное ядро (рис. 4в), окруженное темной или светлой (в КЛ) оболочкой, или и той, и другой. Два зерна (4.1 и 7.1) содержат ядра с реликтами осцилляторной (магматической) зональности. Зерна II типа содержат однородные темные ядра или ядра с пятнистой зональностью (5.1 и 2.1, соответственно), окруженные яркой угловатой или неправильной формы оболочкой. Одно зерно (10.1) является светлым и, практически, однородным.

Анализы как ядер, так и светлых оболочек зёрен характеризуются содержанием U = 141-760 ppm и Th/U соотношением варьирующим, в основном, в пределах от 0,10 до 0,75. Из 14 анализов, выполненных по разным частям зёрен циркона, 13 анализов образуют линию регрессии, расположенную очень близко к конкордии (рис. 6а), хотя только 4 из них являются дискордантными или обратно дискордантными. Один дискордантный анализ ядра (7.1) с осцилляторной зональностью ложится в стороне от линии регрессии и характеризуется значением ${ }^{207} \mathrm{~Pb} /{ }^{206} \mathrm{~Pb}$ возраста $2688 \pm 15$ млн. лет (не показан на рис. 6а). Три других обратно дискордантных анализа ядра и оболочки в цирконе I типа характеризуются статистически неотличимыми значениями ${ }^{207} \mathrm{~Pb} /{ }^{206} \mathrm{~Pb}$ возраста от 1098 \pm 18 млн. лет до 1106 \pm 22 млн. лет (табл. 2, Дополнительные материалы).

Четыре анализа, выполненные по центральным частям зёрен I типа, концентрируются на конкордии в значении возраста $1130 \pm 14$ млн лет (рис. 6а), что интерпретируется как минимальное время кристаллизации протолита ортогнейсов. Четыре

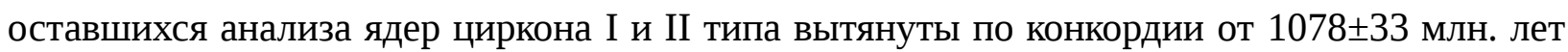
до 837 24 млн. лет, а эллипсоиды их погрешностей частично перекрываются (рис. 6а), предполагая неполную потерю цирконом радиогенного Pb [Vavra et al., 1999]. Три анализа, выполненные по ярким оболочкам и новообразованному зерну (10.1) образуют группу с $\mathrm{U}-\mathrm{Pb}$ возрастом $524 \pm 10$ млн. лет (рис. 6а), что интерпретируется как время роста нового циркона при наложенном термальном событии.

Образцы 59533-4, 59549 и 59549-7 были отобраны из ортопироксеновых (土биотит) ортогнейсов, входящих в состав гранит-гранодиорит-плагиогранитовой ассоциации. Образец 59533-4 отобран в северной части о. Ефремова, а образцы 59549 и 59549-7 представляют, соответственно, массивную и переработанную субширотной зоной милонитизации $\boldsymbol{D}_{4}$ разновидности ортогнейсов на юге острова Ефремова.

Выделенные из образца 59533-4 зёрна циркона являются субпризматическими со скругленными гранями дипирамиды. В КЛ в зёрнах устанавливается ядро с осцилляторной зональностью, окруженное внутренней темной оболочкой (1.1 и 3.1) и, иногда, внешней яркой оболочкой (рис. 4г), дискордантной к внутренней структуре зерна (2.2). Всего было выполнено 14 анализов по различным частям зёрен циркона (табл. 2, Дополнительные материалы). Ядра зёрен характеризуются более низким содержанием $U$ = 
158-543 ppm и значительно более высоким Th/U соотношением $(0,28-0,61)$ по сравнению с оболочками $(\mathrm{U}=661-2925 \mathrm{ppm}, \mathrm{Th} / \mathrm{U}=0.03-0.08)$.

Два дискордантных анализа ядер (11.1 и 6.1) характеризуются значениями ${ }^{207} \mathrm{~Pb} /{ }^{206} \mathrm{~Pb}$ возраста $1126 \pm 22$ млн. лет и $1127 \pm 22$ млн. лет, соответственно. Для анализа внешней оболочки (2.2) рассчитан возраст $895 \pm 24$ млн. лет, а два анализа внутренней оболочки (10.1 и 9.2) дают значения 968 \pm 21 млн. лет и 1058 \pm 17 млн. лет, соответственно. Десять конкордантных анализов ядер распределены цепочкой по конкордии со взаимно перекрывающимися эллипсами погрешностей (рис. 6б). Значительный разброс значений возраста от $1161 \pm 30$ млн. лет до $892 \pm 24$ млн. лет, по-видимому, связан с неполной потерей зернами магматического циркона радиоактивного $\mathrm{Pb}$ или миграцией $\mathrm{U}$ в краевую часть зерна при его перекристаллизации в твердофазном состоянии. В этом случае, наиболее высокое значение возраста, полученное для группы анализов, может отвечать минимальному возрасту кристаллизации магматического циркона [Vavra et al., 1999]. Пять из десяти конкордантных анализов ядер образуют группу с возрастом $1139 \pm 13$ млн. лет (рис. 6б), что интерпретируется как минимальный возраст кристаллизации магматического циркона.

Образец 59549 содержит преимущественно субпризматический циркон со скругленными гранями дипирамиды. В подчиненном количестве находятся овальные зёрна циркона. За исключением овальных зёрен, в большинстве устанавливаются ядра с реликтами осцилляторной зональности, окруженные светло-серыми или яркими в КЛ оболочками (рис. 4д). Граница между ядром и оболочкой может быть дискордантна к внутренней структуре ядра (зёрна 7 и 8) и носить извилистый характер (зерно 9, «SCAzoning» [Vavra et al., 1999]). Извилистая граница ядро-оболочка может указывать на кристаллизацию нового материала циркона после частичного растворения магматического циркона [Geisler et al., 2007].

Было выполнено 13 анализов по различным частям зёрен циркона. Ядра зёрен отличаются несколько боле высоким содержанием U (242-982 ppm) по сравнению с оболочками (79-195 ppm). Th/U соотношение в ядрах и оболочках, за исключением анализа 5.2 не различается.

Один анализ ядра (6.1) оказался обратно дискордантным со значением ${ }^{207} \mathrm{~Pb} /{ }^{206} \mathrm{~Pb}$ возраста 1278 \pm 29 млн. лет (не показан на рис. 7а). Девять анализов, выполненных по ядрам зерен, ложатся на конкордию, со взаимно перекрывающимися эллипсами

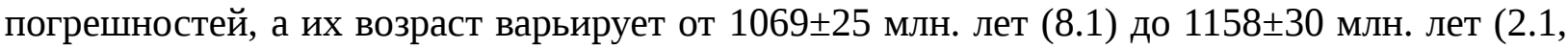
рис. 7а). Разброс значений возраста может быть связан с частичной потерей зернами магматического циркона радиогенного $\mathrm{Pb}$. Поэтому, максимальное значение возраста, полученное по ядрам с осцилляторной зональностью, будет отвечать времени кристаллизации магматического циркона. Шесть анализов ядер образуют когерентную группу со значением возраста $1127 \pm 11$ млн. лет (рис. 7а), что интерпретируется как время кристаллизации магматического циркона в протолите ортогнейсов.

Три анализа оболочек образуют конкордантную группу с возрастом $914 \pm 19$ млн. лет (рис. 7а), что интерпретируется как время образования оболочек при наложенном термальном событии.

Образец 59549-7 содержит зёрна циркона различной морфологии: от субпризматических со скругленными гранями дипирамиды, до овальных зёрен или зёрен неправильных очертаний. В КЛ устанавливается комплексное внутреннее строение зёрен. Как правило, зёрна содержат темное ядро (гомогенное или с реликтами осциллятороной 
зональности), полностью или частично окруженное одинарной (7.1) или многослойной $(6.1,6.2)$ оторочкой, которые могут образовывать «заливы» в центральную часть ядра (рис. 4е). Многослойные оторочки состоят из чередующихся слоев или пятен более темного и более светлого материала циркона. Внешние оторочки, как правило, яркие в КЛ. Зерно 6, кроме того, содержит комплексное ядро, состоящее из внутреннего, тёмного ядра с реликтами зональности и внешнего ядра, яркого в КЛ. Ядра окружены тёмной однородной оболочкой, на краю которой отмечаются светлые пятна.

Зерна часто являются трещиноватыми, а трещины залечены материалом аналогичным ярким внешним оболочкам (8.1, рис. 4е). Такое внутренне строение зёрен свидетельствует в пользу кристаллизации нового материала циркона при наложенных на породу деформациях, сопровождавшихся разрушением/растворением магматического циркона и кристаллизации нового материала как на растворенной поверхности, так и в трещинах, пересекающих зёрна [Geisler et al., 2007].

Ядра зёрен, по сравнению с оболочками, характеризуются несколько более высоким содержанием U (266-828 ppm и 21-361 ppm, соответственно; табл. 2, Дополнительные материалы); Th/U соотношение различается слабо: 0,23-0,40 и 0,14-0,76, соответственно, за исключением темной оболочки 6.2 где оно составляет $0,01$.

Из 12 анализов, выполненных по различным частям зёрен циркона, только один анализ ядра (9.2) со значением ${ }^{207} \mathrm{~Pb} /{ }^{206} \mathrm{~Pb}$ возраста $1091 \pm 15$ млн. лет оказался дискордантным. Остальные анализы ложатся на конкордию (рис. 7б) и разделяются на две основные возрастные группы. Четыре анализа ядер с осцилляторной зональностью могут расцениваться как когерентные (с 95\% доверительным уровнем) с возрастом $1108 \pm 27$ млн. лет. Это значение достаточно хорошо коррелируется с возрастом кристаллизации магматического циркона в обр. 59549. Три анализа ярких внешних оболочек (5.1, 7.1 и 8.1) и анализ яркого внешнего ядра (6.1) образуют конкордантную группу с возрастом 930 16 млн. лет, что статистически неотличимо от анализов оболочек в обр. 59549 и интерпретируется как время метаморфизма ортогнейсов, возможно сопровождавшегося интенсивным рассланцеванием пород в зоне милонитизации $\boldsymbol{D}_{4}$. Один анализ светлой оболочки (3.1) дает значение возраста 1079 \pm 50 млн. лет, что перекрывается с возрастом

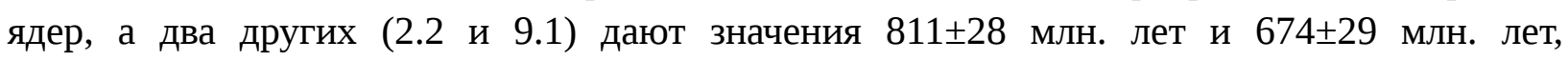
соответственно, что вряд ли имеет геологический смысл. Анализ внешней темной оболочки 6.2 отвечает значению возраста 525 \pm 18 млн. лет, что интерпретируется как максимальное время последнего термального события, наложенного на ортогнейсы.

Образец 59569-9b отобран из интенсивно переработанных субширотной зоной милонитов $\left(\boldsymbol{D}_{4}\right)$ двупироксен-биотитовых лейкогабброноритов. Циркон в этом образце представлен сильно удлинёнными субпризматическими зёрнами или их фрагментами, иногда с корродированными и неровными гранями. Реже отмечаются короткопризматические или овальные зёрна. На КЛ снимках практически во всех зёрнах отмечается пятнистая или полосчатая зональность с чередованием более светлых и более темных полос, параллельных удлинению зёрен (рис. 8а). В единичных случаях (3.1) зерно пресекается тёмно-серым новообразованным материалом циркона, который так же образует внешнюю оболочку зерна. Таким образом, в данном образце не обнаружено зерен циркона с явными признаками первично магматического происхождения.

Семь анализов центральной части зёрен и один анализ новообразованного материала характеризуются достаточно низким содержанием $\mathrm{U}=187-815 \mathrm{ppm}$ и $\mathrm{Th} / \mathrm{U}$ соотношением (за исключением ан. 1.1) в пределах 0.41-1.14. Все анализы оказались практически 
конкордантными. Анализы центральных частей зёрен циркона вытянуты по конкордии и

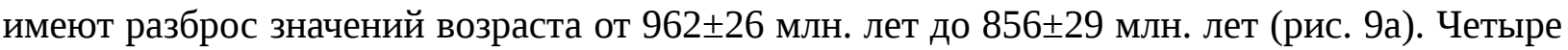
анализа центральных частей зёрен с наиболее высокими значениями ${ }^{206} \mathrm{~Pb} /{ }^{238} \mathrm{U}$ возраста, образуют когерентную группу с U-Pb возрастом 954 \pm 13 млн. лет. Зерна циркона в этом образце не сохранили первично магматическую внутреннюю структуру. Полученное значение возраста, в пределах погрешности, перекрывается с возрастом аплитовидных

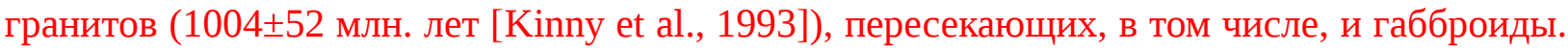
Поэтому, значение 954 \pm 13 млн. лет можно рассматривать как максимальное время их метаморфизма, сопровождавшего развитие зон милонитов $\boldsymbol{D}_{4}$. Анализ новообразованного

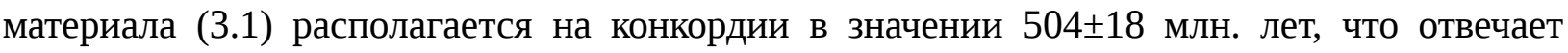
времени его кристаллизации.

Образец 57563 отобран из толщи III комплекса Филла, обнажающегося на полуострове Мазе, и представлен интенсивно мигматизированным и рассланцованным силлиманит-гранат-биотитовым гнейсом. Практически все зерна циркона, выделенные из этого образца, имеют округлую форму и отличаются неоднородным внутренним строением (рис. 8б). В большинстве из них наблюдаются реликты ядра с так называемыми «структурами-призраками» («ghost-texture», [Connely, 2001], - реликтами в той или иной степени сохранившейся магматической зональности, что позволяет отнести их к детритовым. Ядра окружены светлыми внешними оболочками (например, ан. 16) с «пятнистой» зональностью. Резкие границы между ядром и остальной частью зерна наблюдаются в том случае, если между ядром и внешней оболочкой находится темная, незональная внутренняя оболочка (ан. 16). Оболочки, как правило, дискордантны к внутреннему строению ядра (ан. 3), что указывает на их кристаллизацию на растворенной поверхности детритовых ядер [Geisler et al., 2007]. Реже присутствуют зерна, содержащие светлые угловатые ядра (ан. 12) или практически однородные яркие зёрна с «мозаичной» зональностью (ан. 5), аналогичной внешним оболочкам зерен. Образование оболочек и светлых округлых зерен с мозаичной или пятнистой зональностью интерпретируется как результат кристаллизации циркона при метаморфизме [Vavra et al., 1996, Rubatto, 2017].

Был выполнен 21 анализ по различным частям зёрен циркона, четыре из которых оказались дискордантными (Табл. 3, Дополнительные материалы; рис. 9б). Анализ ядра (11.1) с реликтами магматической зональности (не показан на рис. 9б) имеет значение ${ }^{207} \mathrm{~Pb} /{ }^{206} \mathrm{~Pb}$ возраста $3207 \pm 9.2$ млн. лет, а три остальных дискордантных анализа ядер (7, 9 и 12) характеризуются значением ${ }^{207} \mathrm{~Pb} /{ }^{206} \mathrm{~Pb}$ в интервале $1931 \pm 67$ млн. лет до $1984 \pm 21$ млн. лет. Три конкордантных анализа ядер с реликтами магматической зональности $(4,6$ и 14)

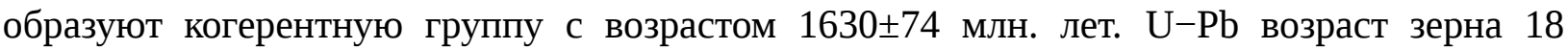
рассчитан с большой погрешностью и составляет 2346 200 млн. лет. Остальные анализы, выполненные по ядрам, светлым оболочкам и однородным ярким зернам, образуют вытянутую по конкордии цепочку взаимно перекрывающихся эллипсов с возрастом от $1127 \pm 90$ млн. лет до 524 \pm 42 млн. лет (рис. 9б). Три анализа из этой группы, выполненные по ядрам с реликтами осцилляторной зональности (зерна 8, 13 и 16), характеризуются наиболее высокими значениями ${ }^{207} \mathrm{~Pb} /{ }^{206} \mathrm{~Pb}$ возраста и при совместно расчёте дают значение $1050 \pm 55$ млн. лет (рис. 9б). Два анализа ярких зерен с мозаичной зональностью

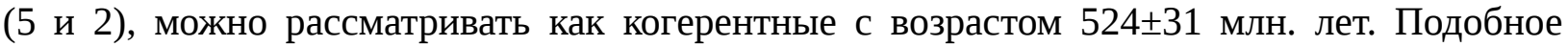
распределение значений возраста интерпретируется как результат частичной или неоднократной потери зернами циркона радиогенного Pb [Vavra et al., 1999] при наложенном термальном событии, максимальный возраст которого соответствует 


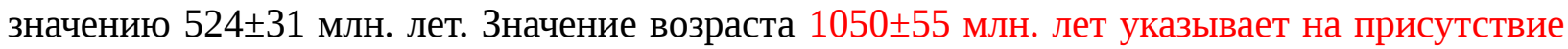
в протолите парагнейсов вещества мезопротерозойского возраста.

\section{Sm-Nd анализ «порода-гранат».}

Для Sm-Nd исследований использовался образец силлиманит-гранат-биотитового гнейса 57563, циркон из которого был исследован методом LA-ICP-MS. Концентрации Sm и $\mathrm{Nd}$ определялись методом изотопного разбавления. Подготовка проб к анализу и измерения производились в ИГГД РАН (С.-Петербург) в статическом режиме на массспектрометре "Triton TI". Коррекция на изотопное фракционирование осуществлялась путем нормализации значений к ${ }^{148} \mathrm{Nd} /{ }^{144} \mathrm{Nd}=0,241570$, а нормализованные значения приводились к ${ }^{143} \mathrm{Nd} /{ }^{144} \mathrm{Nd}=0,511860$ в международном изотопном стандарте La Jolla. Точность определения отношений ${ }^{147} \mathrm{Sm} /{ }^{144} \mathrm{Nd}$ составила $0,5 \%$, а для ${ }^{143} \mathrm{Nd} /{ }^{144} \mathrm{Nd}$ составляет 0,003\%. Навеска зерен граната была разделена на две части, одна из которых подвергалась выщелачиванию в течении 24 часов при температуре $180^{\circ}$ в $98 \%$ растворе $\mathrm{H}_{2} \mathrm{SO}_{4}$, следуя процедуре, описанной в работе [Anczkiewicz, Thirlwall, 2003]. Выщелачивание проводилось с целью исключения влияния таких включений как монацит на изотопный состав граната. Результаты анализа представлены в табл. 4 (Дополнительные материалы).

Образец характеризуется отрицательным значением $\varepsilon \mathrm{Nd}(\mathrm{t})=-11,6$, рассчитанным на возраст 1050 млн. лет, что может свидетельствовать о происхождении его осадочного протолита за счет разрушения пород с длительной коровой историей. Одностадийный модельный возраст породы $\mathrm{t}_{\mathrm{DM}}=3415$ млн. лет, а двухстадийный модельный возраст $\mathrm{t}_{\mathrm{DM2}}=$ 2835 млн. лет, что указывает на преобладании в протолите породы вещества архейского возраста.

Тангенс угла наклона трехточечной линии регрессии, построенной по породе в целом (Wr), исходной (GrtI) и выщелоченной (GrtH) фракциям граната, соответствует значению возраста $513 \pm 150$ млн. лет (рис. 10). Расчеты, выполненные по Wr относительно исходной и выщелоченной фракций граната по отдельности, дают значения возраста $529,3 \pm 4,4$ млн. лет и 511,6 $\pm 3,3$ млн. лет, соответственно. Несовпадающие значения возраста, так же, как и большая погрешность при использовании двух фракций граната, обусловлены более низким значением отношения ${ }^{143} \mathrm{Nd} /{ }^{144} \mathrm{Nd}$ в исходной фракции граната. Это может быть вызвано присутствием в исходном гранате минеральных включений со значительно более низким отношением ${ }^{143} \mathrm{Nd} /{ }^{144} \mathrm{Nd}$, чем в гранате. Поэтому, значение возраста 511,6士3,3 млн. лет принимается за время закрытия Sm-Nd системы в гранате.

\section{ОБСУЖДЕНИЕ РЕЗУЛЬТАТОВ}

Применение прецизионного U-Pb датирования циркона методом SHRIMP [Kinny et al., 1993] позволило установить, что провинция Рёуер сложена породами как архейского, так и протерозойского возраста. Ортогнейсы архейского возраста окружают фрагменты сапфиринсодержащих пород (парагнейсы Мазе), для которых были рассчитаны ультравысокотемпературные (UHT) параметры метаморфизма (950-1050 ${ }^{\circ} \mathrm{C}$ при 9,5-12 кбар с последующей декомпрессией до $>7$ кбар при $>800-850{ }^{\circ} \mathrm{C}$; [Harley, Fitzsimons, 1991; Harley, 1998; Kelsey et al., 2003b; Harley and Kelly, 2007a]), время проявления которого до сих пор остается предметом острых дискуссий. Поэтому, подавляющее большинство петрологических, структурных и изотопно-геохимических исследований было посвящено именно архейским фрагментам коры островов Рёуер. В данной работе приводятся новые геологические и изотопные данные по относительно слабо изученной протерозойской 
части провинции Рёуер, которую предлагается выделить в мезо- неопротерозойский террейн Филла.

На рисунке 11 показано распределение значений конкордного возраста, полученного по зёрнам циркона из всех проанализированных образцов первичномагматических пород террейна Филла. Как видно из рисунка, полученные значения отчетливо подразделяются на три возрастные группы: среднемезопротерозойскую, со значениями возраста в интервале $1408 \pm 26$ млн. лет - $1320 \pm 27$ млн. лет, мезо-

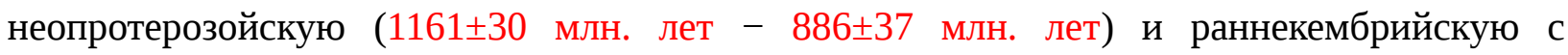

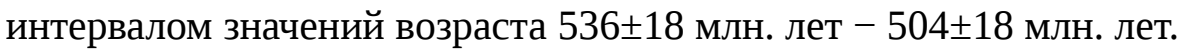

Среднемезопротерозойская группа представлена анализами, которые, за исключением одного, выполнены по первично магматическому циркону из гранатбиотитовых ортогнейсов (обр. 59583). Рассчитанный по ним возраст верхнего пресечения $1364 \pm 17$ млн. лет интерпретируется как время кристаллизации магматического протолита ортогнейсов и, следовательно, минимальное время проявления наиболее раннего (13801340 млн. лет) тектонотермального события в террейне Филла. По времени, это событие коррелируется с возрастом магматизма в террейне Фишер, приведшего 1.4- 1.2 млрд. лет назад [Beliatsky et al., 1994; Kinny et al., 1997, Алексеев и др., 2010] к образованию ювенильной коры провинции Рейнер (Фишерская фаза, [Mikhalsky et al., 1996, 2013]), примыкающей с юга к исследованной территории (рис. 1а).

Мезо-неопротерозойская группа анализов является самой многочисленной и охватывает период времени, соответствующей длительности Биверской фазы (1150-850 млн. лет, рис. 11) Рейнерского тектогенеза в провинции Рейнер [Kinny et al., 1993; Wang et al., 2005, Carson and Grew, 2006; Carson et al., 2007; Liu et al., 2007a, 2007b Mikhalsky et al., 2013;]. На ранней стадии Биверской фазы (1160-1050 млн. лет, рис. 11) в террейне Филла происходило внедрение многочисленных интрузий кислого и основного состава, прорывающих толщи I и II комплекса Филла. Наиболее ранними являются интрузии

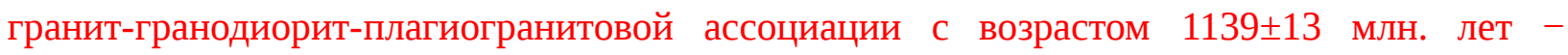
$1108 \pm 27$ млн. лет. Изотопные (Sr-Nd) характеристики этих пород [Sheraton et al., 1984; Kinny et al., 1993] не позволяют предполагать участие архейской коры в их образовании. В свою очередь, гранитоиды прорываются мантийными расплавами, формирующими габбронорит-диоритовую ассоциацию, возраст которой однозначно не установлен. Поскольку габброиды интурдируются жилами аплитов с возрастом 1004 \pm 52 млн. лет [Kinny et al., 1993], то это значение может служить ограничением времени их внедрения. Поэтому, эта стадия относится к периоду роста коры террейна Филла, как за счет внедрения гранитных расплавов, так и мантийных добавок.

$$
\text { Результаты датирования метаморфического (оболочки) или }
$$

перекристаллизованного магматического циркона из интенсивно деформированных пород позволяют выделить более позднюю (1000-900 млн. лет, рис.11) неопротерозойскую стадию эволюции террейна Филла. Зерна циркона из образца 59595-7 кристаллического сланца толщи I комплекса Филла, характеризующегося ярко выраженной сланцеватостью $\mathrm{S}_{3}$ (деформации $\mathrm{D}_{3}$ ), дают значение возраста $1007,4 \pm 9,8$ млн. лет. Близкий возраст (1057+22/-10 млн. лет) получен по циркону из анатектического лейкогранита в базитах этой же толщи. Кристаллизация лейкогранитов предшествовала деформациям $\mathrm{D}_{3}$ [Kinny et al., 1993]. Таким образом, полученное нами значение возраста можно интерпретировать как время одного из ранних эпизодов высокотемпературного (гранулитового) метаморфизма, возможно, синхронного с деформациями $\mathrm{D}_{3}$. Возраст кристаллизации 
оболочек вокруг зёрен магматического циркона из образцов плагиогранитоидов 59549 и 59549-7, в различной степени испытавших деформации $\mathbf{D}_{4}$, находятся в пределах $914 \pm 19$ млн. лет - 930 \pm 16 млн. лет, соответственно, а возраст метаморфического циркона из

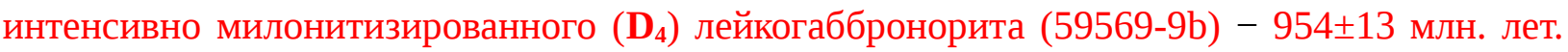

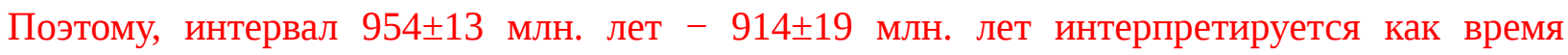
развития субширотных зон милонитов $\left(\mathbf{D}_{4}\right)$ и связанного с ними повторного высокотемпературного (гранулитового) метаморфизма пород. В целом, интервал времени (1000-900 млн. лет) относится к периоду интенсивной тектонотермальной переработки коры, в который объединены выделенные ранее Рёуерское событие (1030-970 млн. лет) и заключительную стадию Рейнерского (950-850 млн. лет) тектогенеза [Harley and Kelly, 2007b; Boger, White, 2003; Boger et al., 2000; Mikhalsky et al., 2013].

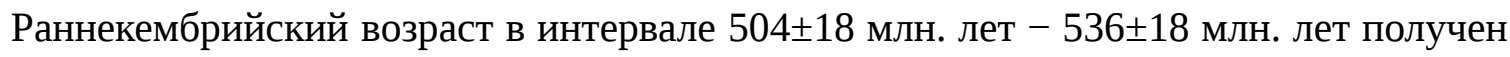
по анализам новообразованных зёрен циркона и оболочек, окружающих незональные ядра с неопротерозойским возрастом и отражает время наиболее молодого термального события в террейне Филла. В провинции Рейнер интервал времени 550-500 млн. лет интерпретируется как одно из основных высокотемпературных тектонотермальных событий (Прюдское событие, [Harley, Kelly, 2007b; Liu et al., 2013]), воздействовавших на породы, расположенные на восточном побережье залива Прюдс [Hensen, Zhou, 1995, Carson et al., 1996; Fitzsimons et al., 1997; Harley and Kelly, 2007b; Mikhalsky et al., 2013; Hokada et al., 2016], т.е. на территории, непосредственно граничащей с исследованным районом. Метаморфическое событие с возрастом 545-510 млн. лет так же было установлено и в пределах провинции Рёуер (например, [Kinny et al., 1993; Harley et al., 1998, Kelsey et al., 2003a, 2003b, 2007, 2008]). Датирование зерен монацита из парагнейсов Мазе, позволило сделать вывод, что этот интервал времени сопровождался высокотемпературным метаморфизмом, достигавшим своего пика (UHT) около 545 млн. лет назад [Tong, Wilson, 2006; Kelsey et al., 2007]. В противоположность этому данные, представленные [Harley, Kelly, 2007b; Hokada et al., 2016], свидетельствуют в пользу того, что UHT метаморфизм был древнее 590 млн. лет. Полученный возраст 511,6ะ3,3 млн. лет закрытия Sm-Nd системы в гранате (обр. 57563) перекрывается как с возрастом кристаллизации оболочек циркона, так и с возрастом кристаллизации син- $\mathbf{D}_{5}$ пегматитов (500 \pm 12 млн. лет, [Kinny et al., 1993]), внедрение которых сопровождалось метаморфизмом вмещающих пород в условиях от амфиболитовой до зеленосланцевой фации [Harley, 1997]. Наиболее общепринятой является точка зрения, что закрытие Sm-Nd системы в гранате происходит при температуре около $600^{\circ} \mathrm{C}$ [Mezger et al., 1992; Ganguly et al., 1998]. Поэтому, полученные значения возраста, как для оболочек зёрен циркона, так и для граната интерпретируются как время остывания пород до температур, максимум, амфиболитовой фации. Это хорошо согласуется с выводом [Harley, Kelly, 2007b], что кристаллизация циркона с возрастом около 510 млн. лет происходила при остывании пород и их взаимодействии с водным флюидом, синхронно с внедрением пегматитов и формированием зон милонитизации $\mathbf{D}_{5}$.

Большие разногласия вызывает как время отложения осадочного протолита парагнейсов Мазе и Филла, так и время, начиная с которого террейны Мазе и Филла развивались совместно. Результаты изучения детритовых зерен циркона из парагнейсов Мазе позволили предположить [Wang et al., 2007], что совместная эволюция этих террейнов началась, как минимум, около 1000 млн. лет назад, а отложение их осадочного протолита, следовательно, предшествовало этому событию. Альтернативная модель, 
впервые предложенная в работе [Hensen, Zhou, 1997], предполагает, что террейны Мазе и Филла были совмещены только в начале кембрия, т.е. в Прюдское тектонотермальное событие. В работе [Kelsey et al., 2008] зёрна циркона с возрастом 989-580 млн. лет, обнаруженные в парагнейсах Мазе и Филла, были интерпретированы как детритовые, что позволило сделать вывод об отложении осадочного протолита парагнейсов после 580 млн. лет, но до Прюдского тектонотермального события. По мнению [Hokada et al., 2016] протолит парагнейсов Мазе откладывался после 1000 млн. лет, а появление популяции циркона с возрастом в интервале 1000-700 млн. лет и даже с возрастом около 580 млн. лет, отражает различный эффект наложения Прюдского события на метаморфический циркон мезопротерозойского возраста.

Исследованный нами образец парагнейса Филла (толща III, обр. 57563) содержит популяцию (6 анализов из 21) зерен циркона с палеопротерозойским ${ }^{207} \mathrm{~Pb} /{ }^{206} \mathrm{~Pb}$ возрастом в интервале 1729-1984 млн. лет. Один дискордантный анализ дает значение ${ }^{207} \mathrm{~Pb} /{ }^{206} \mathrm{~Pb}$ возраста $3207 \pm 9.2$ млн. лет. Это свидетельствует в пользу того, что протолит парагнейсов формировался с участием вещества как архейского, так и палеопротерозойского возраста. Модельный $\mathrm{t}_{\mathrm{DM}}=3415$ млн. лет и $\varepsilon \mathrm{Nd}\left(\mathrm{t}_{1050}\right)=-11,6$ указывают на возможное преобладание в протолите парагнейсов архейского вещества с существенно проэволюционировавшим изотопным составом $\mathrm{Nd}$. Оставшиеся 14 анализов зерен циркона, как отмечалось выше, образуют группу со взаимно перекрывающимися значениями индивидуального возраста от $1127 \pm 90$ млн. лет до 524 \pm 42 млн. лет (рис. 9б, врезка), что интерпретируется как результат различной степени воздействия Прюдского события на циркон мезонеоопротерозойского возраста. Значение $1050 \pm 55$ млн. лет, полученное по трем анализам детритовых ядер с магматической зональностью, говорит о присутствии в составе протолита мезопротерозойского веществ, источником которого могли служить породы гранит-гранодиорит-плагиогранитовой ассоциации. Учитывая данные, представленные в работе [Hokada et al., 2016] и его интерпретацию данных [Kelsey et al., 2008], мы предполагаем, что отложение протолита парагнейсов Филла произошло после внедрения интрузий гранит-гранодиорит-плагиогранитовой ассоциации.

Минимальный возраст парагнейсов Филла ограничивается временем развития субширотных зон милонитов $\boldsymbol{D}_{4}$, которые накладывались, в том числе, и на парагнейсы в интервале $954 \pm 13$ млн. лет - 914 \pm 19 млн. лет назад. Парагнейсы Филла распространены не только в террейне Филла, но и находятся среди архейских ортогнейсов в террейне Мазе [Harley, 1987]. Это означает, что совмещение фрагментов архейской и мезонеопротерозойской коры провинции Рёуер (террейны Мазе и Филла, соответственно) произошло до отложения осадочного протолита парагнейсов Филла, но предшествовало метаморфизму и деформациям пород с возрастом 954-914 млн. лет.

\section{ВЫВОДЫ}

Полученные нами геологические и изотопные данные с учетом результатов предшествующих исследований [Kinny et al., 1993, 1998] позволяют выделить мезонеопротерозойский террейн Филла, который представляет собой фрагмент континентальной коры, сформировавшийся в интервале 1380-900 млн. лет назад. Террейн Филла сложен метаморфизванными в гранулитовой фации метаморфическими и первично интрузивными породами, протолит которых образовывался в интервале времени 1370-1000 млн. лет назад. Приведенные изотопные данные позволяют выделить в 
террейне Филла, как минимум, три периода тектонотермальной активизации: среднемезопротерозойский в интервале времени 1380-1340 млн. лет, мезонеопртерозойский в интервале 1160-900 млн. лет и раннекембрийский в интервале 540-500 млн. лет. Первый период соответствует возрасту среднемезопротерозойского кислого магматизма в террейне Филла и, по времени, коррелируется с Фишерской фазой тектогенеза в провинции Рейнер. Интервал времени 1160-900 млн. лет, в целом, соответствует Биверской фазе тектонотермальной активности провинции Рейнер. В террейне Филла этот период может быть разделен на две стадии: раннюю, с возрастом 1160-1050 млн. лет и позднюю, с возрастом 1000-900 млн. лет. Ранняя стадия интерпретируется как период роста коры за счет гранитоидного и мантийного магматизма,

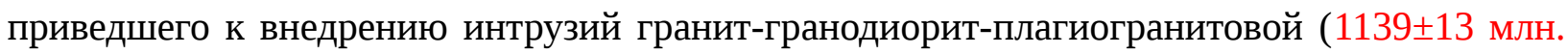
лет - 1108 27 млн. лет) и габбронорит-диоритовой ассоциаций. Интервал 1000-900 млн. лет рассматривается как стадия тектонотермальной переработки коры террейна Филла, сопровождавшаяся интенсивными деформациями и высокотемпературным метаморфизмом пород. На основе полученных и имеющихся данных, мы предполагаем, что отложение осадочного протолита парагнейсов Филла произошло после внедрения пород гранит-гранодиорит-плагиогранитовой ассоциации, но до развития субширотных зон высокотемпературных милонитов $\left(\mathrm{D}_{4}\right)$ с возрастом 954-914 млн. лет. В этом случае, совместная эволюция террейнов Мазе и Филла началась, как минимум, около 1000 млн. лет назад.

Наиболее молодой, раннекембрийский, период тектонической активизации соответствует Прюдскому событию, проявленному как в провинции Рейнер, так и в террейне Мазе провинции Рёуер. Он сопровождался развитием локальных, относительно низкотемпературных зон милонитов и внедрением синкинематических жил пегматитов. Таким образом, тектонотермальная эволюция террейна Филла практически полностью соответствует основным фазам роста и переработки коры провинции Рейнер. Следовательно, террейн Филла представляет собой фрагмент провинции Рейнер, присоединенный к архейскому террейну Мазе, как минимум, в конце мезопротерозоя.

Благодарности. Авторы благодарны А.В. Травину и анонимному рецензенту за глубокие и конструктивные отзывы, позволившие улучшить качество представляемых материалов и выводов. Работа частично выполнена при поддержке РФФИ (грант 15-0502761). 


\section{Список литературы}

Алексеев Н.Л., Зингер Т.Ф., Глебовицкий В.А., Капитонов И.Н. Изотопный U-Pb возраст магматизма и метаморфизма пород массива Фишер (Восточная Антарктида) и его значение для геодинамических реконструкций // ДАН, 2010, т. 435, с. 69-75.

Михальский Е.В., Шератон Дж. Рейнерская тектоническая провинция Восточной Антарктиды: вещественный состав и геодинамический режим формирования // Геотектоника, 2011 (6), с. 88-106.

Михальский Е.В., Боровков Н. В., Гонжуров Н. А., Гоголев М. А., Светов С. А., Кунаккузин Е. Л. Реконструкция неопротерозойско-кембрийского орогенеза на Земле Принцессы Елизаветы (Восточная Антарктида по данным изучения гранитоидов // Геотектоника, 2018 (4), с. 23-53.

Равич М.Г., Каменев Е.Н. Кристаллический фундамент Антарктической платформы. Л.: Гидрометеоиздат, 1972, 658 с.

Anczkiewicz R., Thirlwall M.F. Improving precision Sm-Nd and Rb-Sr garnet dating be $\mathrm{H}_{2} \mathrm{SO}_{4}$ leaching - a simple solution to the phosphate inclusion problem. In: Vance D., Muller W., Villa I.M. (Eds), Geochronology: linking the isotopic record with petrology and texture. Geological Society London Special Publications, 2003, v. 220, p. 83-91.

Beliatsky B. V., Laiba A. A., Mikhalsky E. V. U-Pb zircon age of the metavolcanic rocks of Fisher Massif (Prince Charles Mountains, East Antarctica) // Antarctic Science, 1994, v. 6, p. 355-358.

Black L.P., Kamo S.L., Williams I.S., Mundil R., Davis D.W., Korsch R.J., Foudoulis C. The application of SHRIMP to Phanerozoic geochronology: a critical appraisal of four zircon standards // Chemical Geology, 2003, v. 200, p. 171-188. 335-371.

Boger S.D. Antarctica - Before and after Gondwana // Gondwana Research, 2011, v. 19, p.

Boger S.D., White R.W. The metamorphic evolution of metapelitic granulites from Radok Lake, northern Prince Charles Mountains, east Antarctica: evidence for an anticlockwise P-T path // Journal of Metamorphic Geology, 2003, v. 21, p. 285-298.

Boger S.D., Carson C.J., Wilson C.J.L., Fanning,C.M. Neoproterozoic deformation in the Radok Lake region of the northern Prince Charles Mountains, east Antarctica; evidence for a single protracted orogenic event // Precambrian Research, 2000, v. 104, p. 1-24.

Carson C.J., Fanning C.M., Wilson C.J.L. Timing of the Progress Granite, Larsemann Hills, evidence for Early Palaeozoic orogenesis within the East Antarctic Shield and implications for Gondwana assembly // Australian Journal of Earth Sciences, 1996, v. 43, p. 539-553.

Carson C.J., Grew E.S. Geology of the Larsemann Hills Region Antarctica (1:25000 scale map). AFSO-Geoscience Australia, Canberra, 2006.

Carson C.J., Grew E.S., Boger S.D., Fanning C.M., Christy A.G. Age of boron- and phosphorus-rich paragneisses and associated orthogneisses, Larsemann Hills: New constraints from SHRIMP U-Pb zircon geochronology. In: Cooper A.K., Raymond C.R., et al. (Eds), A Keystone in a Changing WorldOnline Proceedings of the 10th ISAES. USGS Open File Report 2007-1047, 2007. Extended Abstract 003, 4 pp.

Connelly J. N. Degree of preservation of igneous zonation in zircon as a signpost for concordancy in U/Pb geochronology // Chemical Geology, 2001, v. 172 , p. $25-39$.

Dirks P.H.G.M., Wilson C.J.L. Crustal evolution of the east Antarctic mobile belt in Prydz Bay: continental collision at 500 Ma? // Precambrian Research, 1995, v. 75, p. 189-207.

Fitzsimons I.C.W., Kinny P.D., Harley, S.L. Two stages of zircon and monazite growth in anatectic leucogneiss: SHRIMP constraints on the duration and intensity of Pan-African metamorphism in Prydz Bay, East Antarctica // Terra Nova, 1997, v. 9, p. 47-51. 
Fitzsimons I.C.W. A review of tectonic events in the East Antarctic Shield and their implications for Gondwana and earlier supercontinents // Journal of African Earth Sciences, 2000, v. 31, p. 3-23.

Fitzsimons I. C. W. Proterozoic basement provinces of southern and southwestern Australia, and their correlation with Antarctica. In: Yoshida M., Windley B., Dasgupta S. (Eds), Proterozoic East Gondwana: Supercontinent Assembly and Breakup: Geological Society London Special Publications, 2003, v. 206, p. 93-130.

Ganguly J., Tirone M., Hervig R. L. Diffusion kinetics of Samarium and Neodymium in garnet, and a method for determining cooling rates of rocks // Science, 1998, v. 281, p. 805.

Geisler T., Schaltegger U., Tomaschek F. Re-equilibration of zircon in aqueous fluids and melts // Elements, 2007, v. 3, p. 25-30.

Harley S.L. Precambrian geological relationships in high-grade gneisses of the Rauer Group Islands, east Antarctica // Australian Journal of Earth Sciences, 1987, v. 34, p. 175-207.

Harley S.L. Ultrahigh temperature granulite metamorphism $\left(1050{ }^{\circ} \mathrm{C}, 12 \mathrm{kbar}\right)$ and decompression in garnet (Mg70)-orthopyroxene-sillimanite gneisses from the Rauer Group, East Antarctica // Journal Metamorphic Geology, 1988, v. 16, p. 541-562.

Harley S.L. Archaean-Cambrian development of East Antarctica: metamorphic characteristics and tectonic implications. In: Yoshida M., Windley B.F. (Eds), Proterozoic East Gondwana: Supercontinent Assembly and Breakup. Geological Society of London Special Publications, 2003, v. 206, p. 203-230.

Harley S.L., Fitzsimons I.C.W. Pressure-temperature evolution of metapelitic granulites in a polymetamorphic terrane: the Rauer Group, East Antarctica // Journal of Metamorphic Geology, 1991, 9, 231-243.

Harley S.L., Snape I., Fitzsimons I.C.W. Regional correlations and terrane assembly in East Prydz Bay: evidence from the Rauer Group and Vestfold Hills // Terra Antartica, 1995, v. 2, p. 49-60.

Harley S.L., Kelly N.M. Ancient Antarctica: The Archean of the East Antarctic Shield. In: Van Kranendonk M.J., Smithies R.H., Bennett V.C. (Eds), Earth's Oldest Rocks. Developments in Precambrian Geology series, v. 15. Elsevier, 2007a, p. 149-186.

Harley S.L., Kelly N.M. The impact of zircon-garnet REE distribution data on the interpretation of zircon $\mathrm{U}-\mathrm{Pb}$ ages in complex high-grade terrains: An example from the Rauer Islands, East Antarctica // Chemical Geology, 2007b, v. 241, p. 62-87.

Harley S.L., Snape I., Fitzsimons I.C.W. Regional correlations and terrane assembly in East Prydz Bay: evidence from the Rauer Group and Vestfold Hills // Terra Antartica, 1995, v. 2, p. 49-60.

Harley S.L., Snape I., Black L.P., 1998. The evolution of a layered metaigneous complex in the Rauer Group, East Antarctica: evidence for a distinct Archaean terrane. Precambrian Research 89, 175-205.

Hensen B.J., Zhou B. A Pan-African granulite facies metamorphic episode in Prydz Bay, Antarctica: evidence from Sm-Nd garnet dating // Australian Journal of Earth Sciences, 1995, v. 42, p. 249-258.

Hensen B.J., Zhou B. East Gondwana amalgamation by Pan-African collision? Evidence from Prydz Bay, Eastern Antarctica. In: Ricci C.A. (Ed.), The Antarctic Region: Geological Evolution and Processes. Terra Antarctic Publications, Siena, 1997, p. 115-119.

Hokada T., Harley S.L., Dunkley D.J., Kelly N.M., Yokoyama K. Peak and post-peak development of UHT metamorphism at Mather Peninsula, Rauer Islands: zircon and monazite $\mathrm{U}-\mathrm{Th}-\mathrm{Pb}$ and REE chemistry constraints // Journal of Mineralogical and Petrological Sciences, 2016, v. 111, p. 89-103.

Kelsey, D.E, Powell, R., Wilson, C.J.L., Steele, D.A. (Th+U)-Pb monazite ages from AlMg-rich metapelites, Rauer Group, east Antarctica // Contributions to Mineralogy and Petrology, 2003a, v. 146, p. 326-340. 
Kelsey D.E., White R.W., Powell R., Wilson C.J.L., Quinn C.D. New constraints on metamorphism in the Rauer Group, Prydz Bay, east Antarctica // Journal of Metamorphic Geology, 2003b, v. 21, p. 739-759.

Kelsey D.E., Hand M., Clarke C., Wilson C.J.L. On the application of in situ monazite chemical geochronology to constraining $\mathrm{P}-\mathrm{T}-\mathrm{t}$ histories in high temperature $\left(>850{ }^{\circ} \mathrm{C}\right)$ polymetamorphic granulites from Prydz Bay, East Antarctica // Journal of the Geological Society of London, 2007, v. 164, p. 667-683.

Kelsey D.E., Wade B.P., Collins A.S., Hand M., Sealing C.R., Netting A. Discovery of a Neoproterozoic basin in the Prydz Belt in east Antarctica and its implications for Gondwana assembly and ultrahigh temperature metamorphism // Precambrian Research, 2008, v. 161, p. 355-388.

Kinny P.D. Monazite U-Pb ages from east Antarctic granulites: comparisons with zircon U-Pb and garnet Sm-Nd ages // Geological Society of Australia Abstracts, 1998, v. 49, p. 250.

Kinny P.D, Black L.P., Sheraton J.W. Zircon ages and distribution of Archaean and Proterozoic rocks in the Rauer Islands // Antarctic Science, 1993, v. 5, p. 193-206.

Kinny P. D., Black L. P., Sheraton J. W. Zircon U-Pb ages and geochemistry of igneous and metamorphic rocks in the northern Prince Charles Mountains // AGSO Journal of Australian Geology and Geophysics, 1997, v. 16, p. 637-654.

Liu X.C., Zhao Y., Zhao G., Jian P., Xu G. Petrology and geochronology of granulites from the McKaskle Hills, eastern Amery Ice Shelf, Antarctica, and implications for the evolution of the Prydz Belt // Journal of Petrology, 2007, v. 48, p. $1443-1470$.

Liu X., Zhao Y., Hu J. The c. 1000-900 Ma and c. 550-500 Ma tectonothermal events in the Prince Charles Mountains-Prydz Bay region, East Antarctica, and their relations to supercontinent evolution. In: Harley S.L., Fitzsimons I.C.W., Zhao Y. (Eds), Antarctica and Supercontinent Evolution. Geological Society London Special Publications, 2013, v. 383, p. 95-112.

Ludwig K.R., User's manual for Isoplot/Ex, Version 3.00, A geochronological toolkit for Microsoft Excel. Berkeley Geochronology Center Sp. Publ., Berkeley, USA, 2003.

Mezger K., Essene E. J., Halliday A. N. Closure temperatures of the Sm-Nd system in metamorphic garnets // Earth and Planetary Science Letters, 1992, v. 113, p. 397.

Mikhalsky E.V., Sheraton J.W., Laiba A.A. \& Beliatsky B.V. Geochemistry and origin of Mesoproterozoic metavolcanic rocks from Fisher Massif, Prince Charles Mountains, East Antarctica // Antarctic Science, 1996, v. 8, p. 85-104.

Mikhalsky E.V., Sheraton J.W., Kudriavtsev I.V., Sergeev S.A., Kovach V.P., Kamenev I.A., Laiba A.A. The Mesoproterozoic Rayner Province in the Lambert Glacier area: its age, origin, isotopic structure and implications for Australia- Antarctic correlations. In: Harley S.L., Fitzsimons I.C.W., Zhao Y. (Eds), Antarctica and Supercontinent Evolution. Geological Society London Special Publications, 2013, v. 383, p. 35-57.

Mikhalsky E.V., Alexeev N.L., Kamenev I.A., Egorov M.S., Kunakkuzin E.L. Mafic dykes in the Rauer Islands and Vestfold Hills (East Antarctica): a chemical and Nd isotopic comparison // Precambrian Research, 2019, v. 329, p. 273-293.

Sheraton J.W., Black L.P., McCulloch M.T. Regional geochemical and isotopic characteristic of high-grade metamorphics of the Pryds Bay area: the extent of Proterozoic reworking of Archaean continental crust in East Antarctica// Pricambrian Research, 1984, v.26, p. 169- 198.

Sims J.P., Dirks P.H.G.M., Carson C.J., Wilson C.J.L. The structural evolution of the Rauer Group, East Antarctica: mafic dykes as passive markers in a composite Proterozoic terrain // Antarctic Science, 1994, v. 6, p. 379-394.

Sims J.P., Wilson C.J.L. Strain localisation and texture development in a granulite-facies shear zone-the Rauer Group, east Antarctica. In: Ricci C.A. (Ed.), The Antarctic Region: Geological Evolution and Processes. Terra Antartica Publication, Siena, 1997, p. 131-138. 
Rubatto D. Zircon: The Metamorphic Mineral// Reviews in Mineralogy and Geochemistry, 2017, v. 83, p. 261-295.

Tingey R.J. The regional geology of Archaean and Proterozoic rocks in Antarctica. In: Tingey R.J. (Ed.), The geology of Antarctica. Oxford, 1991, p. 1-58.

Tong L., Wilson C.J.L. Tectonothermal evolution of the ultrahigh temperature metapelites in the Rauer Group, east Antarctica // Precambrian Research, 2006, v. 149, p. 1-20.

Vavra G, Gebauer D, Schmid R, Compston W. Multiple zircon growth and recrystallization during polyphase Late Carboniferous to Triassic metamorphism in granulites of the Ivrea Zone (Southern Alps): An ion microprobe (SHRIMP) study // Contributions to Mineralogy and Petrology, 1996, v. 122, p. 337-358/

Vavra G., Schmid R., Gebauer D. Internal morphology, habit and U-Th-Pb microanalysis of amphibolite-to-granulite facies zircons: geochronology of the Ivrea Zone (Southern Alps) // Contributions to Mineralogy and Petrology, 1999, v. 134, p. 380-404.

Wang Y., Liu D., Ren L., Williams I.S. Geochemical characteristics and ion microprobe age of the mafic granulites from the Larsemann Hills, east Antarctica // Geochimica et Cosmochimica Acta, 2005, v. 69 (10), A292-A1292 (Supplements).

Wang Y., Tong L., Liu D. Zircon U-Pb ages from an ultra-high temperature metapelite, Rauer Group, east Antarctica: Implications for overprints by Grenvillian and Pan-African events In: Cooper A.K., Raymond C.R., et al. (Eds.), A Keystone in a Changing World -Online Proceedings of the 10th ISAES. USGS Open File Report 2007-1047, 2007.

Wiedenbeck M., Alle P., Corfu F., Griffin W.L., Meier M., Oberli F., Von Quadt A., Roddik J.C., Spiegel W. Three natural zircon standards for U-Th-Pb, Lu-Hf, trace element and REE analyses // Geostandards Newsletter, 1995, 19, p. 1-23.

Wilson C.J.L., Quinn C., Tong L., Phillips D. Early Palaeozoic intracratonic shears and post-tectonic cooling in the Rauer Group, Prydz Bay, East Antarctica constrained by ${ }^{40} \mathrm{Ar} /{ }^{39} \mathrm{Ar}$ thermochronology // Antarctic Science, 2007, v. 19, p. 339-353. 


\section{Подписи к рисункам}

Рис. 1. (а) Упрощённая тектоническая схема Восточной Антарктиды и положение района работ. (б) Геологическая схема островов Рёуер.

Условные обозначения. На (а): 1 - раннедокембрийские ядра; 2 мезопротерозойские и/или неопротерозойские подвижные пояса (в том числе включающие на некоторых участках переработанные фрагменты раннедокембрийских образований); 3 неопротерозойско-кембрийская тектонотермальная переработка; 4 - предполагаемые коллизионные зоны (по [Fitzsimons, 2003; Boger, 2011]); 5 - континентальный ледниковый покров и шельфовые ледники. В - провинция Вестфолль; ГПЧ - горы Принс-Чарльз; ЗП залив Прюдс, $\mathrm{P}$ - Рукерская провинция.

На (б): Террейн Мазе (1-2): 1 - ортогнейсы преимущественно архейского возраста; 2 - парагнейсы Мазе; Террейн Филла (3-10): 3 - гранат-биотитовые (士ортопироксен) ортогнейсы; комплекс Филла (4-6): 4 - толща I; 5 - толща II; 6 - толща III; 7 - гранитгранодиорит-плагиогранитовая ассоциация; 8 - габбронорит-диоритовая ассоциация; 9 порфировидные гранодиориты и диориты; 10 - чарнокитоиды; 11 - докембрий нерасчлененный; 12 - зоны развития милонитов; 13 - место отбора образцов на изотопный анализ; 14 - элементы залегания сланцеватости и метаморфической полосчатости; 15 ледник.

Рис. 2. Выходы горных пород комплекса Филла. (а) Полосчатые кристаллические сланцы (метабазиты Филла) толщи I комплекса Филла (о. Филла), интрудированные жилами чарнокитоидов; (б) тонкое чередование двупироксеновых и гранатсодержащих (рыжее) кристаллических сланцев толщи II комплекса Филла (о. Ефремова); (в) тонкополосчатые плагиогнейсы с прослоями кристаллических сланцев (о. Ефремова); (г) гранат-биотитовые ортогнейсы с реликтами порфировидных вкрапленников калиевого полевого шпата.

Рис. 3. Выходы первично-интрузивных пород террейна Филла. (а)-(б) Гранитгранодиорит-плагиогранитовая ассоциация: (а) ортопироксенсодержащие рассланцованные плагиограниты, интрудирующие кристаллические сланцы толщи I комплекса Филла (о. Ефремова); (б) гранодиориты, интенсивно рассланцованные на контакте с жилой гранитов (слева) и приобретающие полосчатую гнейсовидную текстуру (о. Филла). (в)-(е) Габбронорит-диоритовая ассоциация: в) мигматизированные диориты (светлое), интрудирующие полосчатые кристаллические сланцы толщи I комплекса Филла (о. Филла); (г) плагиоклаз-порфировидные габбронориты, инъецированные (светлое, справа) жилой аплитов (о. Ефремова); (д) лейкогаббронорит с удлиненными по сланцеватости вкрапленниками ортопироксена (рыжее), окруженными зернами клинопироксена (зелёное; о. Филла); (е) лейкогаббронорит с деформированными вкрапленниками клинопироксена (зелёное), окруженные скоплениями зерен ортопироксена и биотита (рыжее; о. Филла).

Рис. 4. Внутреннее строение (КЛ) зерен циркона из исследованных первичномагматических пород террейна Филла. Эллипсами показаны проанализированные участки. Цифры соответствуют номерам анализов в табл. 2 и ссылкам на них в тексте.

Рис. 5. U-Pb диаграммы с конкордией для анализов циркона из образцов: а) гранатбиотитового ортогнейса (обр. 59583) и б) двупироксен-роговообманкового кристаллического сланца (обр. 59595-7). Эллипсы погрешностей соответствуют 2б. 
Рис. 6 Рис. U-Pb диаграмма с конкордией для анализов циркона из образцов: а) биотит-ортопироксенового ортогнейса (обр. 59508) и б) ортопироксен-биотитового ортогнейса (обр. 59533-4). Эллипсы погрешностей соответствуют $2 \sigma$.

Рис.7. U-Pb диаграмма с конкордией для анализов циркона из образцов ортопироксен-биотитовых ортогнейсов: а) образец 59549 и б) образец 59549-7. Тёмносерыми эллипсами показаны анализы оболочек зёрен циркона. Пунктиром выделены анализы ядер, для которых рассчитан конкордный возраст. Эллипсы погрешностей соответствуют $2 \sigma$.

Рис. 8. Внутреннее строение зёрен циркона (КЛ) из образцов: а) лейкогаббронорита (обр. 59569-9б) и силлиманит-гранат-биотитового парагнейса (обр. 57563). Эллипсами показаны проанализированные участки. Цифры соответствуют номерам анализов в табл. 2 и ссылкам на них в тексте.

Рис. 9. $\mathrm{U}-\mathrm{Pb}$ диаграмма с конкордией для анализов циркона из: а) лейкогаббронорита (обр. 59569-9б) и б) силлиманит-гранат-биотитового парагнейса (обр. 57563). На врезке (б): тёмно-серым показаны анализы ядер. Эллипсы погрешностей соответствуют $2 \sigma$.

Рис. 10. Результаты Sm-Nd анализа для образца парагнейса 57563. Wr - порода в целом, GrtI - начальная фракция граната, GrtH - выщелоченная фракция граната. Параметры линий регрессии показаны на рисунке.

Рис. 11. Гистограмма распределения значений U-Pb возраста конкордантных анализов зёрен циркона и относительная вероятность их значимости для проанализированных первично магматических пород террейнаФилла. Использованы конкордные значения возраста. Затемненные вертикальные полосы соответствуют интервалам времени проявления основных тектонотермальных событий в провинции Рейнер; жирным пунктиром показаны условные границы ранней и поздней стадий Биверской фазы активизации. 
Табл. 1. Последовательность тектономагматических событий в провинции Рёуер.

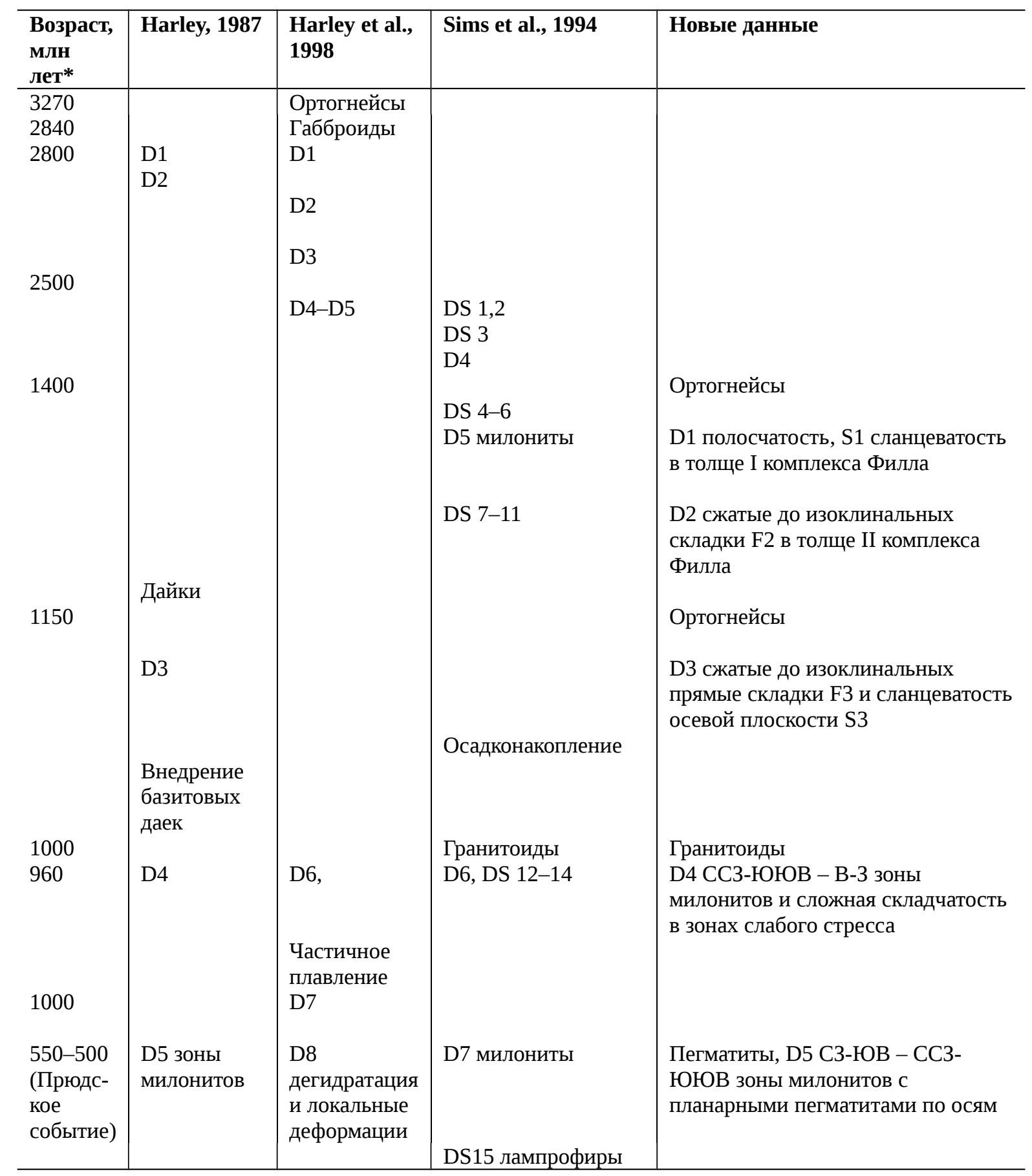

D - деформация, DS - генерация даек. * По данным [Harley, 1987; Harley et al., 1998; Kinny et al., 1993]. 


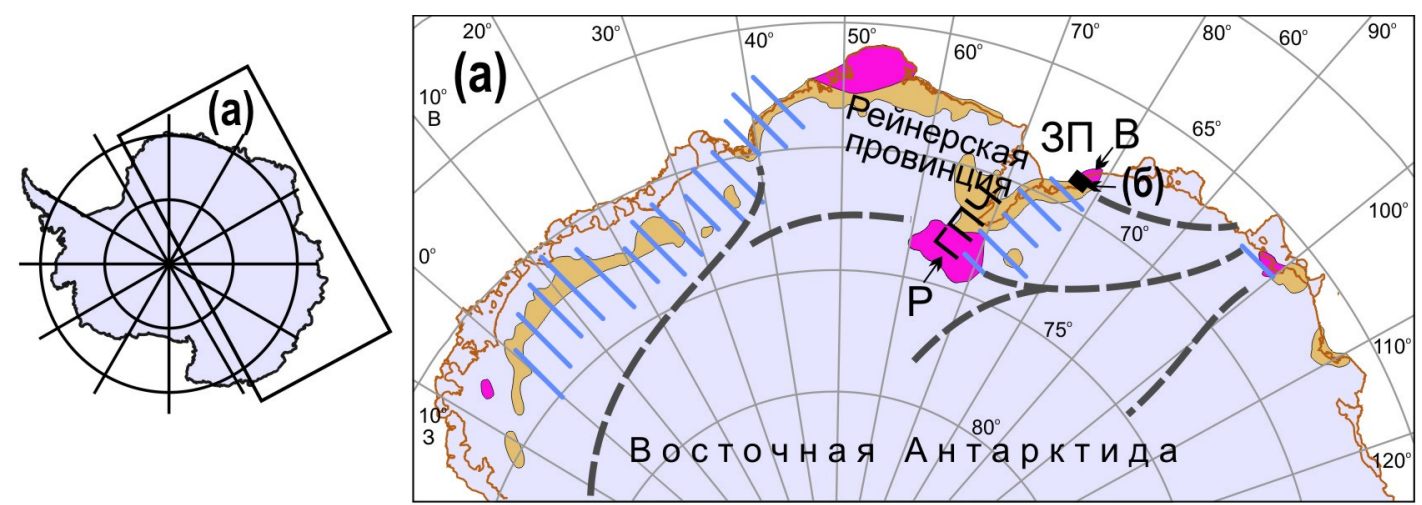

$\square, \square 2 \Delta \backslash \square_{3} \longrightarrow \square_{5}$
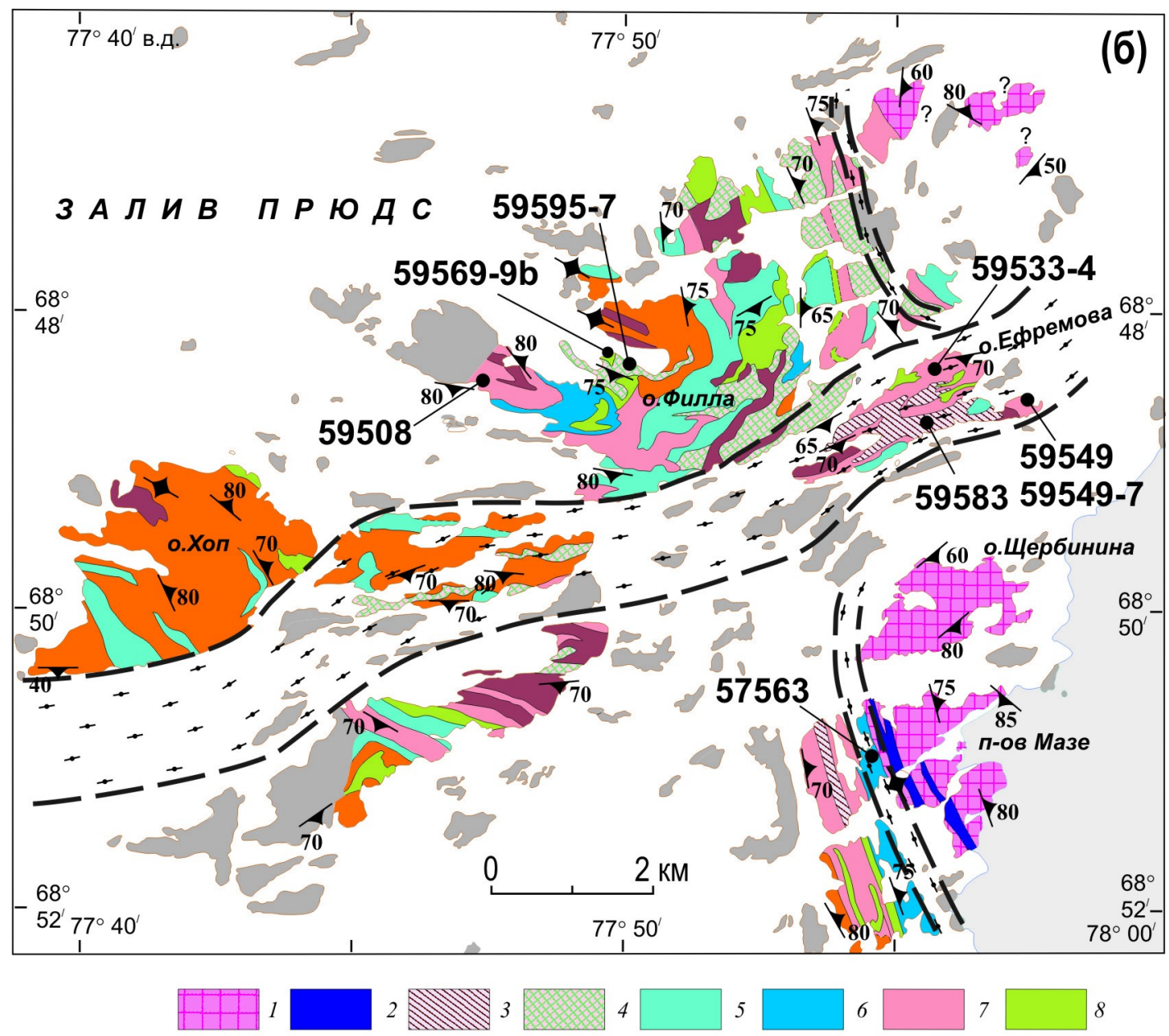

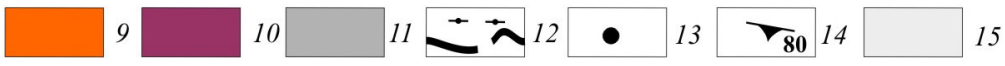



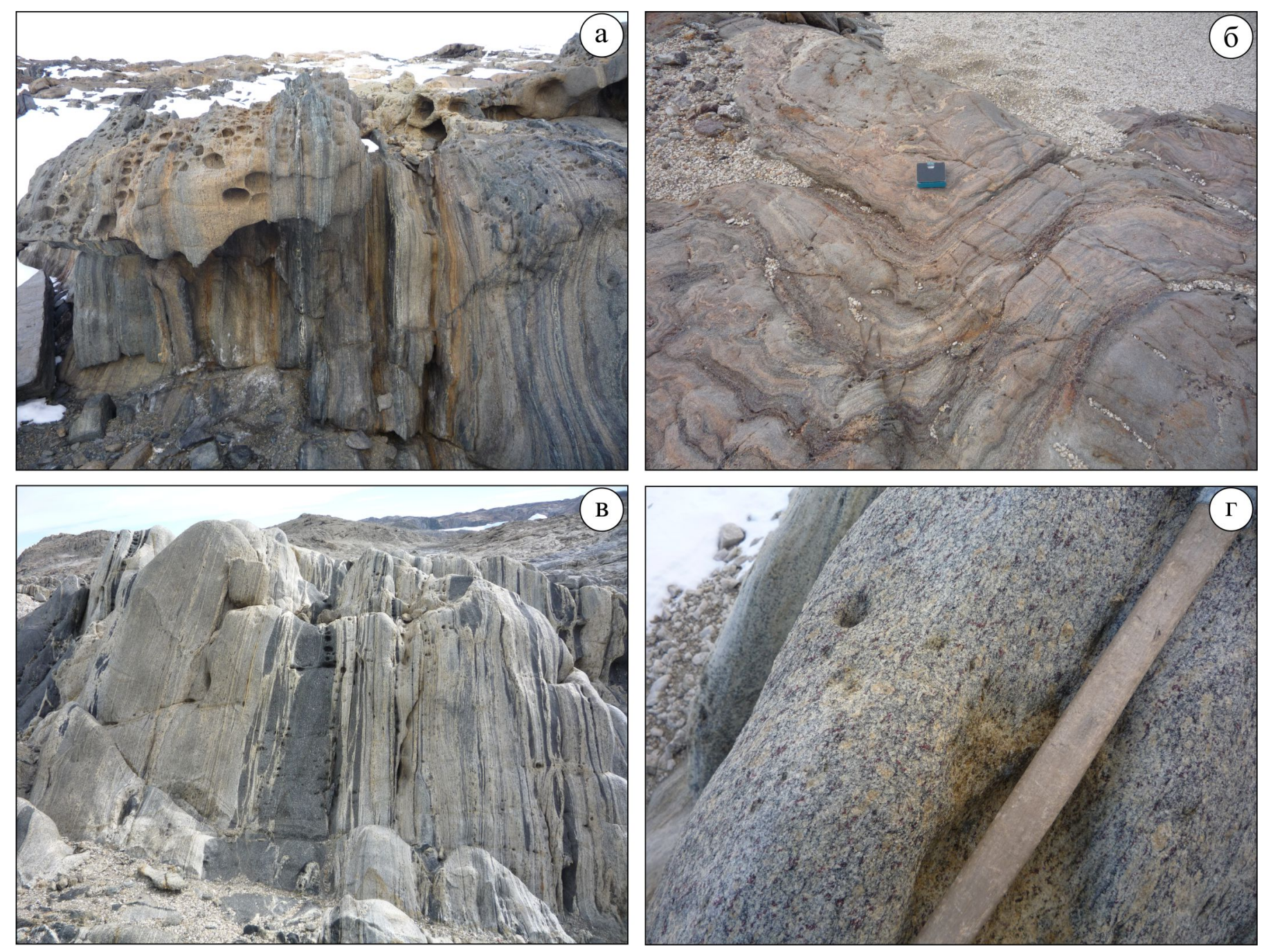

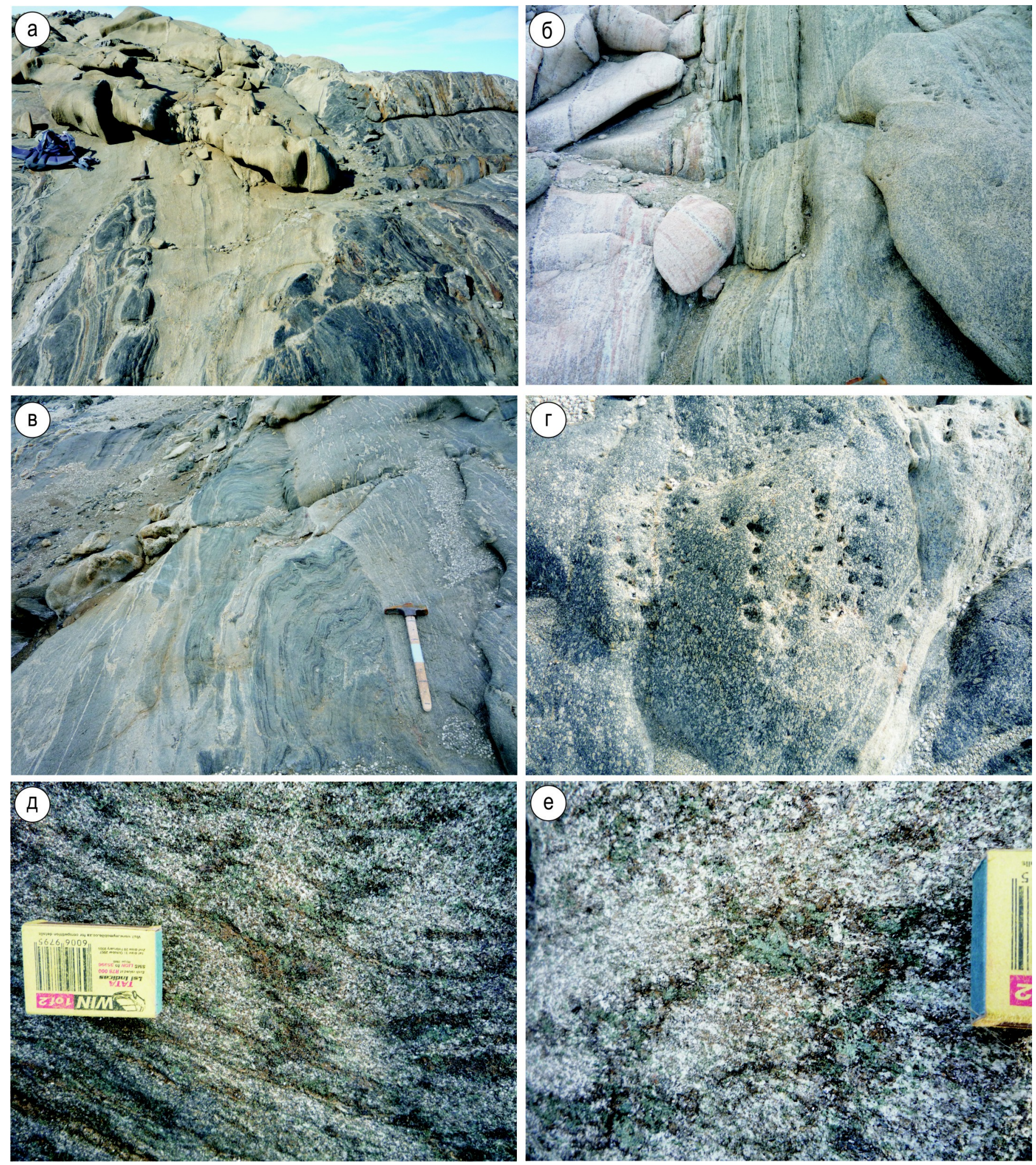

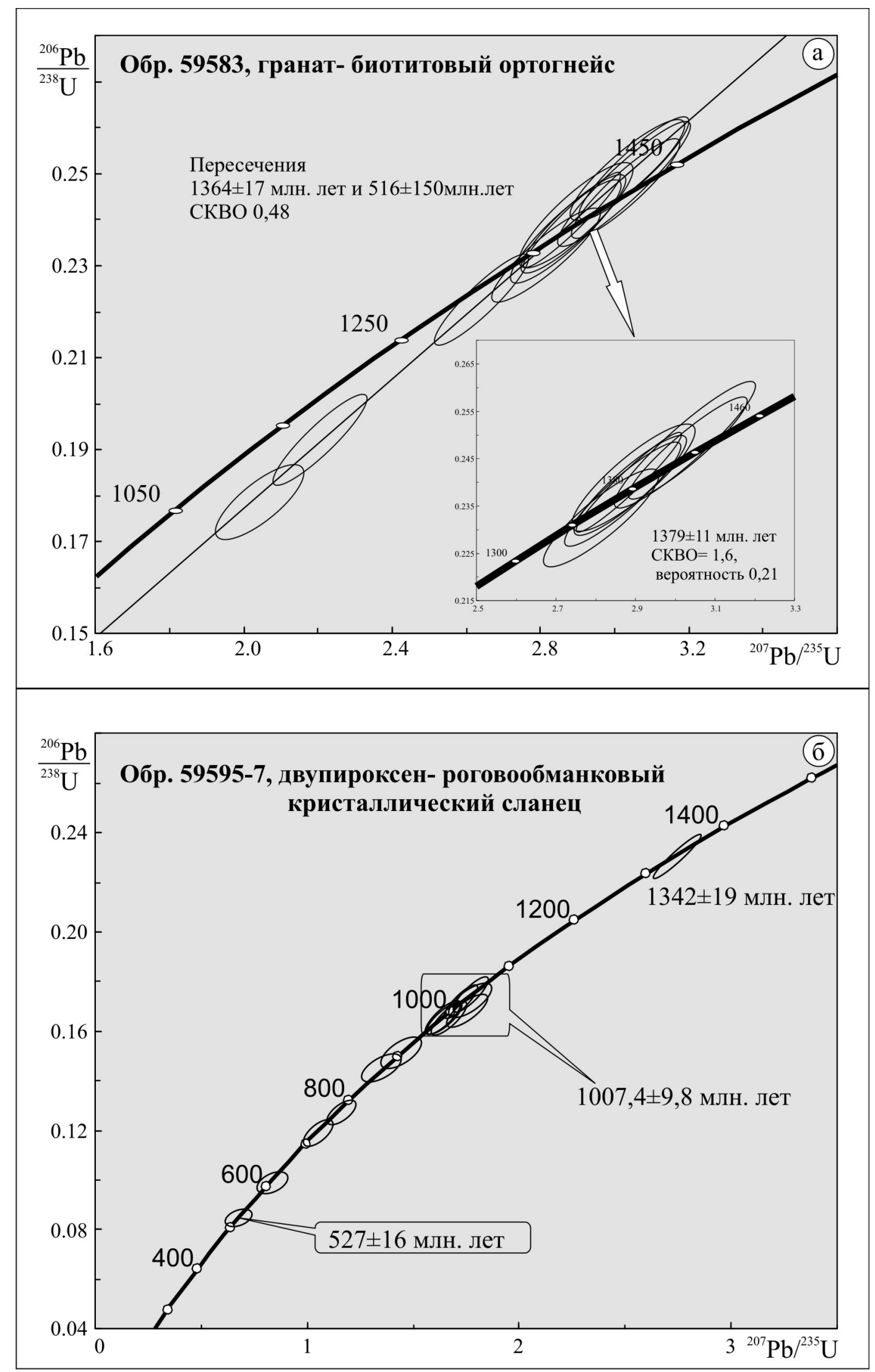

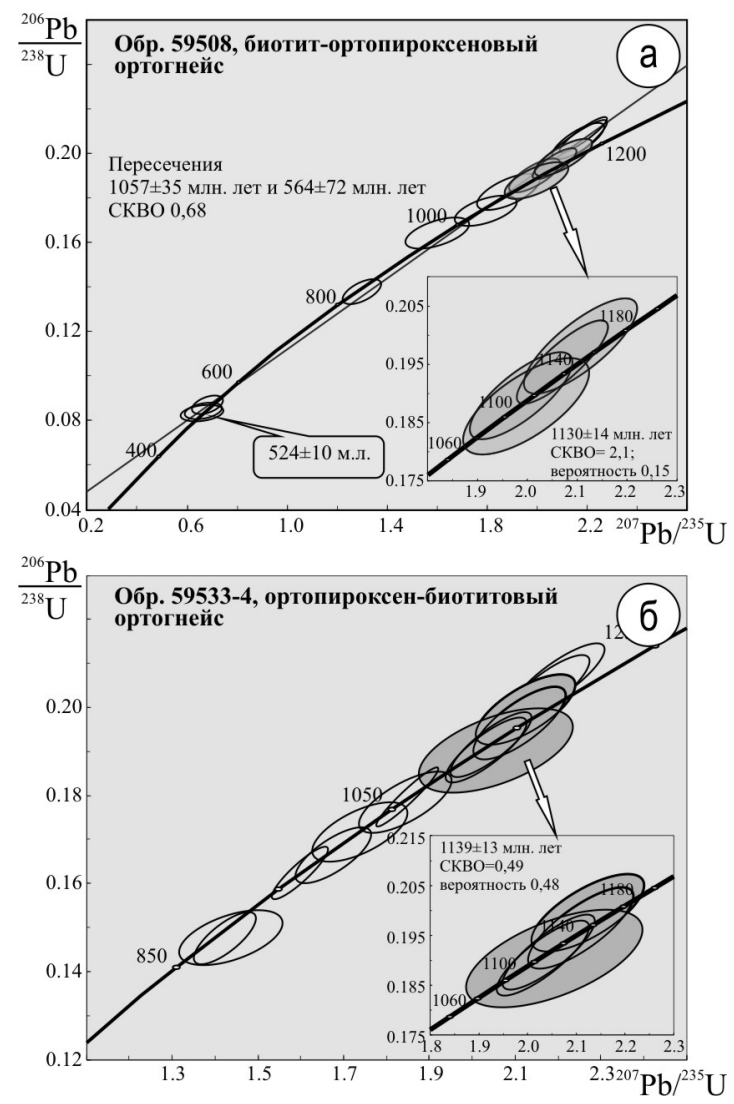

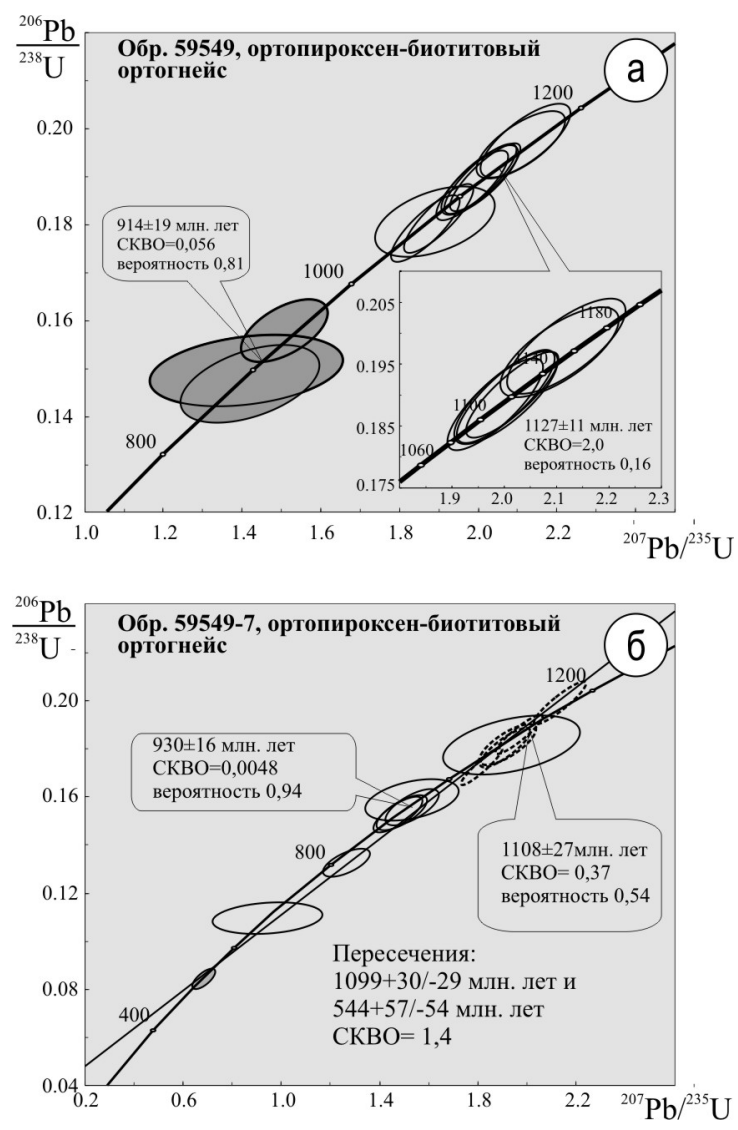


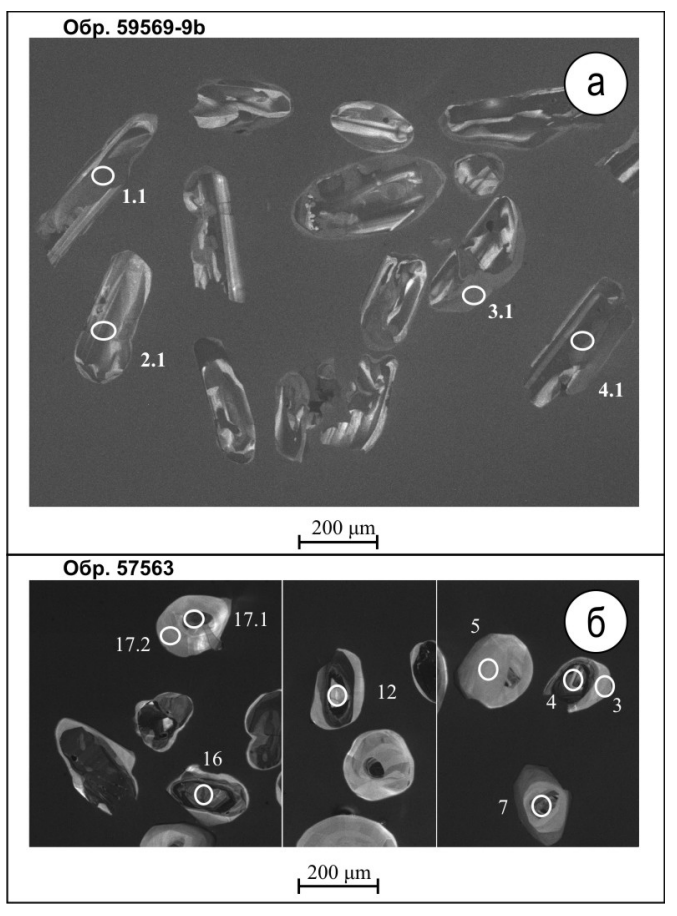




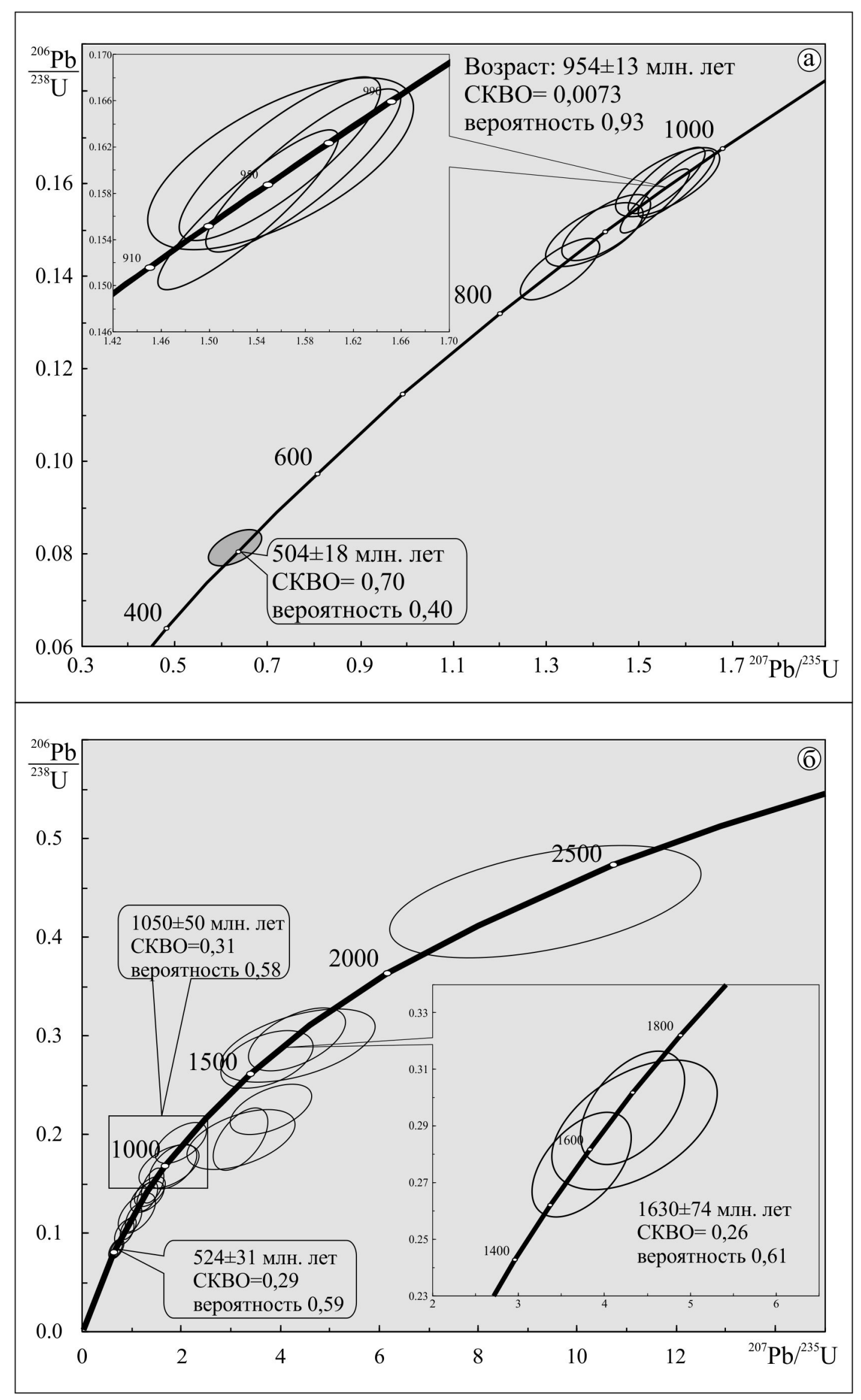




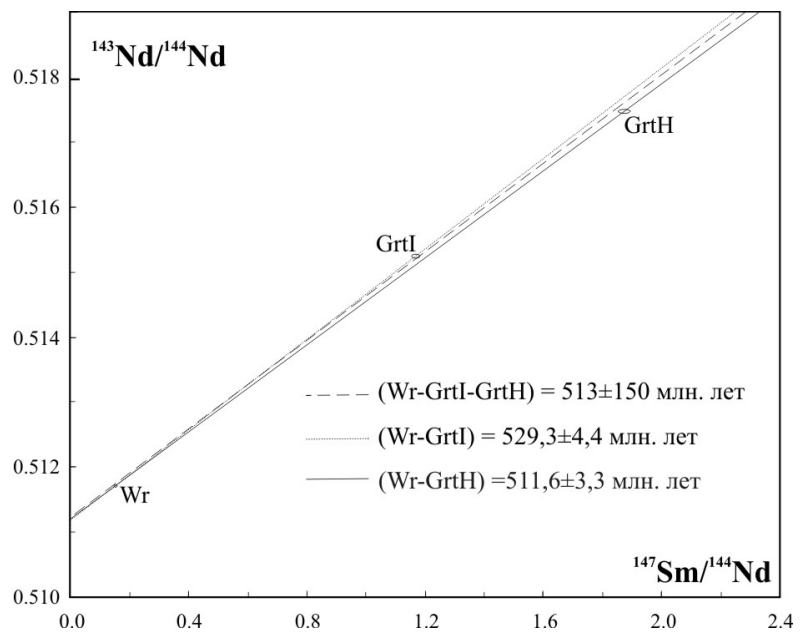




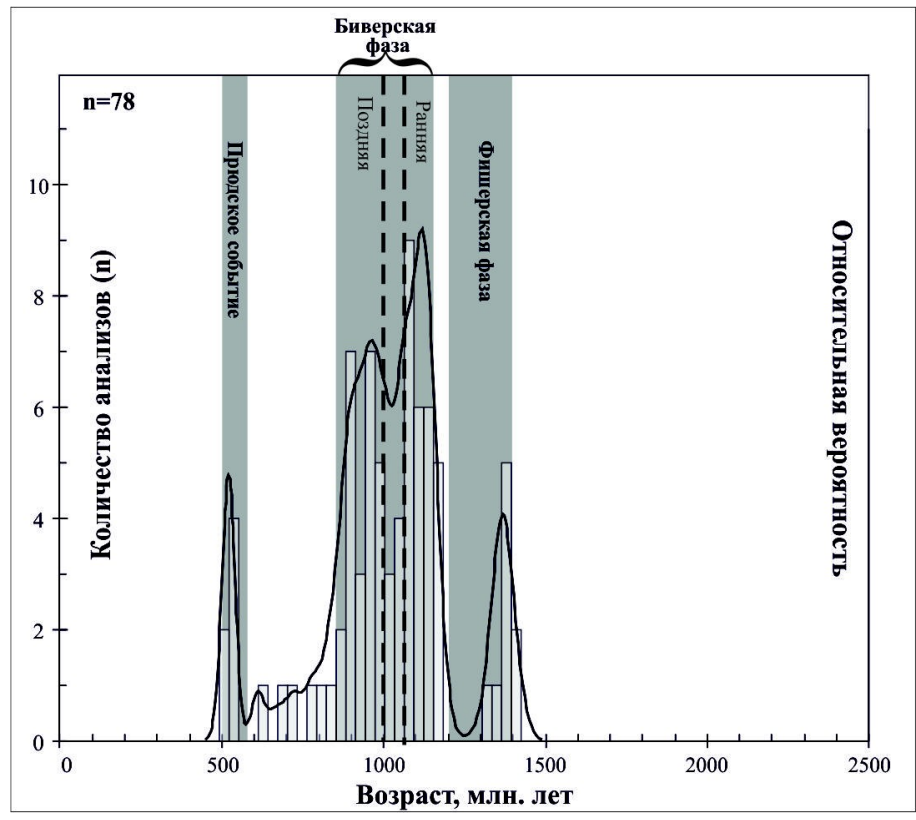




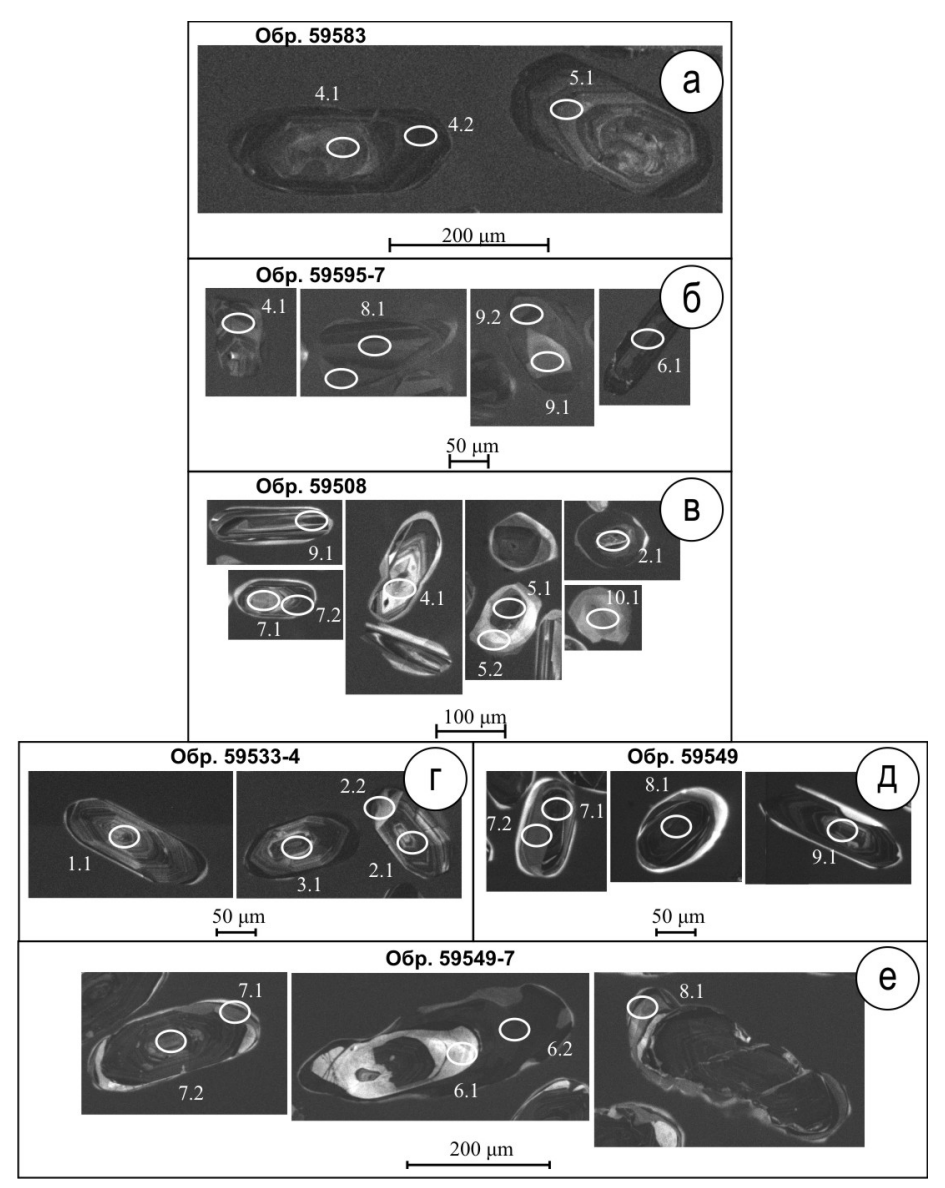

